\title{
Probiotics, prebiotics, synbiotics in prevention and treatment of inflammatory bowel diseases
}

\author{
Tanja Petreska Ivanovska ${ }^{1 *}$, Maja Jurhar Pavlova ${ }^{2}, K_{\text {Kristina Mladenovska }}{ }^{\text {, }}$ \\ Lidija Petrushevska-Tozi ${ }^{1}$
} ${ }^{1}$ Faculty of Pharmacy, University “Ss. Cyril and Methodious”, Mother Theresa 47, Skopje, Republic of Macedonia
${ }^{2}$ Faculty of Medicine, University "Ss. Cyril and Methodious", 50 Division 6, Skopje, Republic of Macedonia

Received: July 2014; Accepted: September 2014

\begin{abstract}
Probiotics, prebiotics, and synbiotics are functional components able to exert positive effects on human health. Numerous medical conditions lack effective and safe approaches for prevention or treatment, thus usage of probiotics, prebiotics, and synbiotics is an alternative. Further, the benefit related to the consumption of these compounds is associated with lower morbidity of chronic diseases and reduced health-care costs. Various types of mediums to deliver probiotics/synbiotics to the human GIT are used. Although capsules and tablets are frequently applied as delivery systems for probiotics, the major challenge of the commercial sector is to market new functional foods containing probiotics and/or prebiotics. Discovering of new probiotic/synbiotic functional foods is connected to the interest of the food industry to revitalize continuously through introduction of products with improved nutritional value and pleasant taste, but also with health benefit for the consumers. The review provides insights and new perspectives in respect to usage of functional components and foods in prevention and treatment of inflammatory bowel diseases (IBD) that are highly correlated with the modern lifestyle. The therapeutic and safety properties of probiotics and prebiotics, their role in pathogenesis of IBD, potential to prevent and treat these diseases as well as postulated mechanisms of action will be discussed, highlighting the main areas in which further research is an emergence.
\end{abstract}

Keywords: probiotic, prebiotic, synbiotic, functional foods, inflammatory bowel disease

\section{Introduction}

The primary role of human diet is to provide sufficient nutrients that supply energy to maintain physiologic processes and well-being. At this level all foods are functional and the intake of some bioactive ingredients like unsaturated fatty acids, fibers, vitamins and essential minerals is enabled by common diet. However, there is a new concept comprising specific features of the use of foods to promote optimal health and reduce the risk of

\footnotetext{
* phone: 38923126 032; fax: + 38923123054
}

e-mail: tpetreska@ff.ukim.edu.mk diseases. Foods that contain compounds known to provide additional benefit beside the basic nutrition are classified as functional foods. Probiotics and prebiotics and both together termed synbiotics are bioactive components attracting much attention nowadays, although their use as fermented foods containing beneficial microbes, particularly lactic acid bacteria have been used by humans for thousands of years. Scientific evidence about the impact of beneficial microorganisms on the well-being of humans dated back 1990s (Ouwehand and Röytiö, 2015). Actually, the concept of functional food was introduced in Japan on the proposal of Ministry of Health and Welfare due to the 
escalation of healthcare costs and aiming improved quality of life of elderly people during the 1980s as foods for specific health use (FOSHU) (Ashwell, 2002). In general, functional foods include conventional foods, modified foods (fortified, enhanced, or enriched), medical foods, and foods for special dietary use (ADA, 2009). Economic growth increases the profit and expenditure improving the quality of life, but implicates diseases associated with the lifestyle. It is well known that the modern lifestyle, increased use of drug and drug toxicity and risks of adverse effects initiate the development of functional foods and pharmaceuticals as safe approach to improve the health. This leads to evolution of new era in healthcare system with the food industry gaining the research role similar as pharmaceutical industry.

Alternative application of probiotics, prebiotics and synbiotics in prevention and treatment of different diseases engendered the researchers to study the benefits and risks related to the consumption of these functional compounds. Various mechanisms of actions of probiotics and prebiotics contributing to improved health have been postulated (Fig. 1). Probiotics have demonstrated efficacy for a number of inflammatory conditions, including arthritis (So et al., 2008), necrotizing enterocolitis (Ezaki et al., 2008), atopic dermatitis and eczema (Kukkonen et al., 2007; Wickens et al., 2008), ulcerative colitis (UC) (Pronio et al., 2008; Fujimori et al., 2009) and Crohn's disease (CD) (Fujimori et al., 2007). Probiotics are known to reduce the symptoms of lactose intolerance (He et al., 2008), while their antihypertensive effects, anticholesterolemic and anticarcinogenic effects are subject of intensive research (Gill and Prasad, 2008; Lye et al., 2009). However, further research is essential as the data originating from the studies with experimental animals and clinical studies with relatively low number of subjects are insufficient to derive evident conclusions. Observed effects for one probiotic strain are specific and cannot be extrapolated to another strain of the same species or genus without confirmation in separate studies (Aureli et al., 2011). The standpoint of strain-specificity of properties of different probiotic species further complicates the evaluation of probiotic effects as well as their potential application in prophylaxis and treatment of diseases.

Development of new therapeutics, including probiotics and prebiotics, which can reduce intestinal inflammation and restore balance of the gastrointestinal microbiota

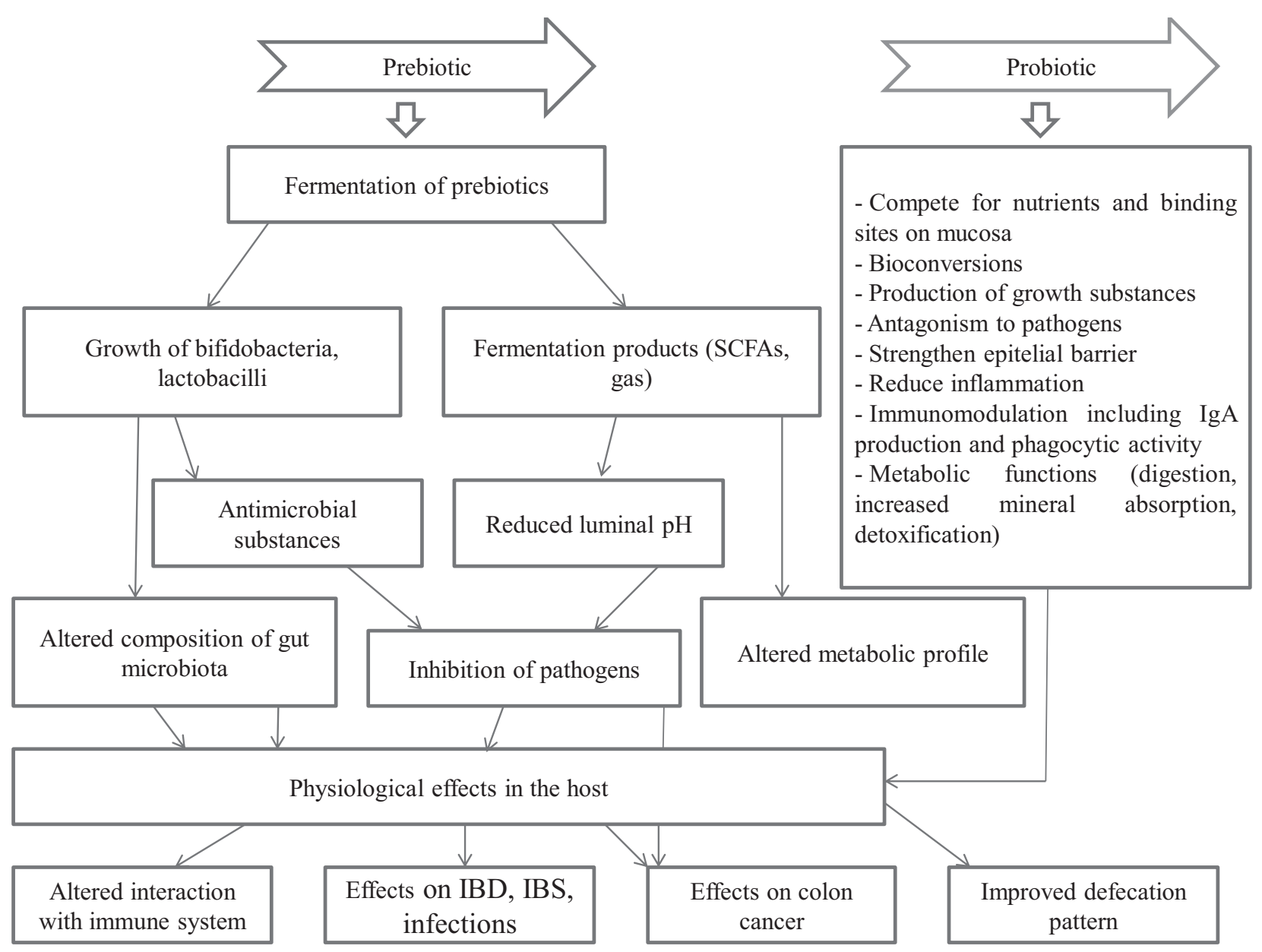

Fig. 1. Mechanisms of action of probiotics and prebiotics. 
due to increased prevalence of IBD with the socioeconomic development in Western society (Looijer-van Langen and Dieleman, 2009; Prisciandaro et al., 2009; Shanahan, 2012). Interactions among the immune system, the gut microbiota and the host genotype are thought to underlie the pathogenesis of IBD. A large number of host susceptibility genes responsible to maintain the mucosa barrier function have been identified (Wapenaar et al., 2008). Genetic predisposition with a loss of antigen tolerance is characterized by alteration in the pattern of cytokine production by $\mathrm{T}$ cell subclasses leading to overlay aggressive $\mathrm{T}$ cell responses to a subset of commensal enteric bacteria and misbalance between beneficial and pathogenic enteric bacteria (Kaser and Blumberg, 2011; Adolph et al., 2013). This aggressive $\mathrm{T}$ cell response followed by immune activation, mucosal damage and permanent inflammation that usually develops in genetically susceptible individuals is considered the main factors involved in IBD etiology together with the environmental factors. Environmental factors responsible for the onset and reactivation of IBD includes lifestyle, diet, socio-economic conditions, and use of non-steroid anti-inflammatory drugs, psychological stress and the presence of caecal appendix (Strober et al., 2007; Neuman and Nanau, 2012). The current therapy strategies include administration of antibiotics, 5-aminosalicilates, non-steroid anti-inflammatory drugs like mesalazine, steroid drugs like cor- tisol and immune-suppressive agents, which reduce symptoms of IBD (abdominal pain, bleeding, diarrhea), but are often associated with severe side effects (Hörmannsperger and Haller, 2010). Although the precise etiology of IBD remains unknown, the major role of gut microbiota in development and persistence of IBD highlighted the importance of interactions between microbiota and host in health and diseases. In this respect, modification of intestinal microbiota composition by using probiotic organisms in order to restore tolerance to microbial antigens of the host's own microbiota is extensively explored. The induction of regulatory versus effector immune responses at the gut mucosa can be modulated by diet-induced changes in the composition of the gut microbiome. Therefore, modulation of gut microbiota composition with fermented milk products, probiotics and prebiotics may contribute to improved health, reduction of diseases or disease symptoms and support of established treatments (Ceapa et al., 2013) and is being researched as a promising prophylactic and therapeutic tool against gut inflammation. This new therapeutic approach is supported by the ability of the intestinal microbiota to regenerate itself completely (Guarner and Malagelada, 2003) and also by multifactorial mechanism of the disease. Main factors enrolled in pathogenesis of IBD and therapeutic strategies are schematically presented in Fig. 2.

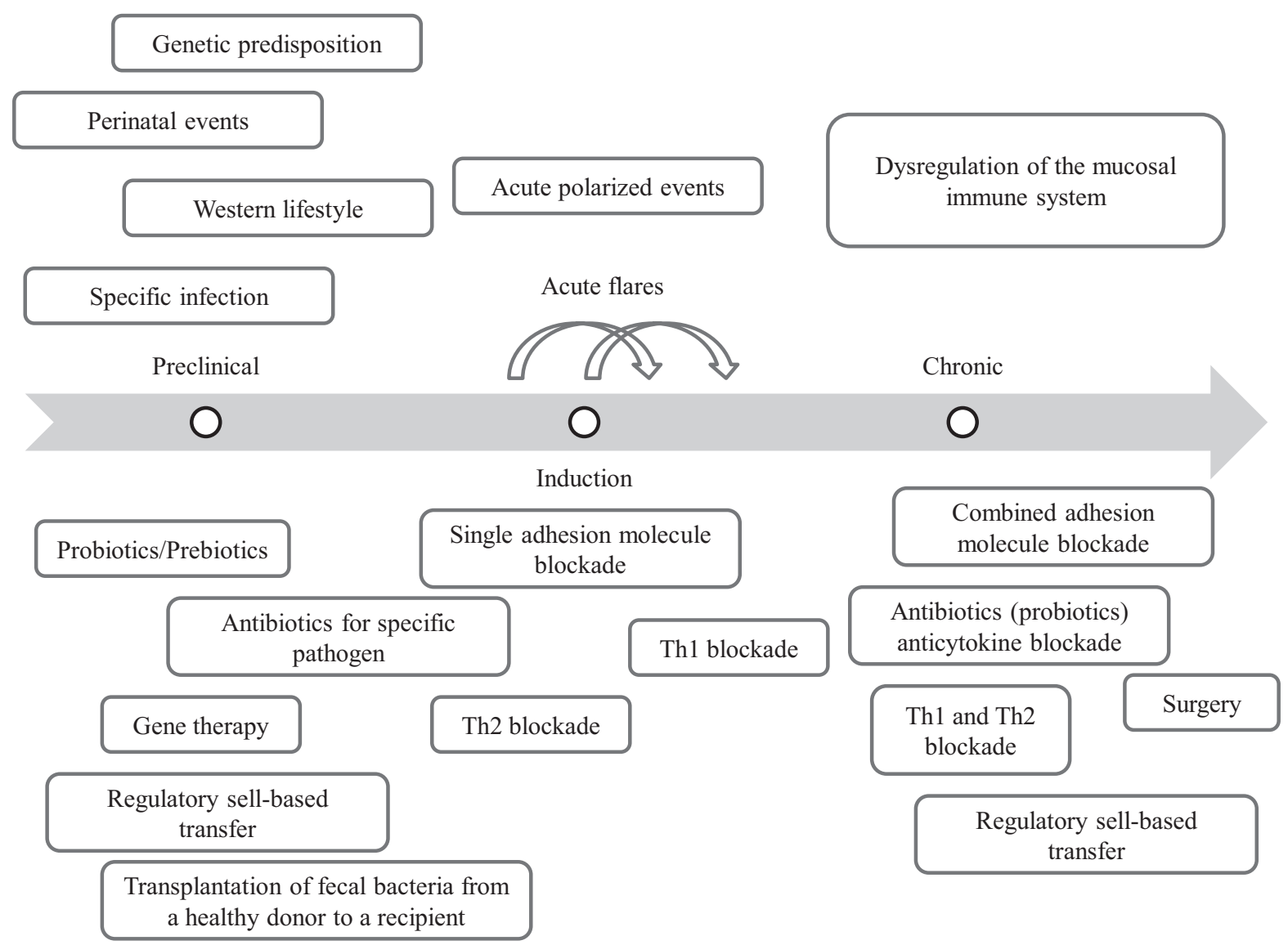

Fig. 2. Ethiopathogenesis and therapeutic strategies of IBD. 
The concept and development of probiotic/synbiotic foods, evaluation of their characteristics as well as their safety aspects are discussed in this paper. Therapeutic relevance of probiotics, prebiotics and synbiotics in the context of IBD and evidences of their efficacy in a form of pharmaceuticals and functional foods are also discussed. Moreover, areas of research that are emerged to be further investigated are pointed.

\section{Probiotics, prebiotics, synbiotics}

Positive effects of lactic acid bacteria on human health were firstly recognized in the $19^{\text {th }}$ century when the Russian Nobel Elie Metchnikoff established the concept of probiotics (Metchnikoff, 1907). Lactic acid bacteria can produce lactic acid from sugars by fermentation and the metabolism of these microorganisms was used for fermentation and preservation of food for centuries. Metchnikoff believed that the long life of the Bulgarian farmers due to the consumption of fermented dairy products. Almost in the same time, the French scientist Tissier has found the positive relationship between bifidobacteria present in the infant microflora fed by mother's milk and improved symptoms of diarrhea (Tissier, 1984). These scientifically confirmed data explained prescribing of yoghurt to treat diarrhea and other intestinal disorders by Hippocrates, as well as existence of some scriptures documented the usage of yoghurt in treatment of different illnesses (Lourens-Hattingh and Viljoen, 2001).

Probiotics are defined as live microorganisms that, when administered in adequate amounts, confer a health benefit to the host (FAO/WHO, 2001). In addition, it is assumed that probiotics improve microbial balance in the intestines. The level of viable probiotics needed to obtain a clinical effect is often quoted as $\geq 10^{6} \mathrm{cfu} / \mathrm{ml}$ in the small bowel and $\geq 10^{8} \mathrm{cfu} / \mathrm{ml}$ in the colon (Bertazzoni Minelli and Benini, 2008). Lactobacillus and Bifidobacterium strains are the most used as probiotics (Ranadheera et al., 2010). Lactic acid bacteria grow optimally at $\mathrm{pH}$ 5.5-5.8 and their growth is supported in the presence of the nutritional compounds like amino acids, fatty acids, peptides, nucleotide basis, vitamins and minerals (Hayek and Ibrahim, 2013). Some species are aero-tolerant and may utilize oxygen through the enzyme flavoprotein oxidase, while others are strictly anaerobic. Other microorganisms also known to possess probiotic properties include Escherichia coli Nissle, Saccharomyces boulardii, Streptococcus thermophilus, Enterococcus francium, Propionibacterium, Pediococcus, and Leuconostoc, but some strains of these microorganisms are known to be pathogenic (Senoc et al., 2005).

Probiotic organisms evaluated using in vitro and in vivo evaluation tests prove that they show: resistance to gastric acidity, bile acid resistance and resistance to intestinal enzymes, adherence to mucus or human epithelial cells and cell lines, antimicrobial activity against potentially pathogenic bacteria, ability to reduce pathogen adhesion to surfaces, bile salt hydrolase activity and resistance to spermicides if applied for vaginal use (Saarela et al., 2000; Petrushevska and Mladenovska, 2009). Production of pathogen-inhibitory substances, competition with pathogenic bacteria for epithelial adhesion sites, nutrient competition and production, degradation of toxins and toxin receptors and modulation of immune and non-specific host responses are several health protection mechanisms of probiotics able to exert within the gut (Prakash et al., 2011).

According to the most recent definition "A prebiotic is a selectively fermented ingredient that allows specific changes, both in the composition and/or activity in the gastrointestinal microbiota that confers benefits upon host well-being and health" (Gibson et al., 2004; Macfarlane et al., 2006). Several criteria have to be fulfilled when a substance is to be classified as prebiotic: safety, stability, organoleptic properties, resistance to digestion in the upper bowel and fermentability in the colon, as well as the ability to promote the growth of beneficial bacteria in the gut (Gibson, 2004). Carbohydrates as oligofructose, fructooligosaccharides (FOS), inulin, galacto-oligosaccharides (GOS), transgalacto-oligosaccharides, soybean-oligosaccharides, gluco-oligosaccharides, xylo-oligosaccharides, gentio-oligosaccharides, isomalto-oligosaccharides, lactulose and polysaccharides as starch and pectins are considered to be effective prebiotics (de Vrese and Schrezenmeir, 2008). However, majority of studies on prebiotics have focused on inulin-type fructans (inulin, FOS) and GOS which selectively stimulate the growth of bifidobacteria (Guarner, 2013) and have been linked to long-lasting safe commercial use (Macfarlane et al., 2008). These compounds are most often used as prebiotics and specified as bifidogenic oligosaccharides (Birkett and Francis, 2010). Bifidogenic oligosaccharides reaching the colon intact are fermented to short chain fatty acids (SCFAs) and followed by production of gases by colonic bacteria (Meyer and Stasse-Wolthuis, 2009). These products of carbohydrates fermentation, acetate, propionate and butyrate as the main SCFAs and lactate as important intermediate in the formation of SCFAs are thought to be beneficial to host health. Chemical conversion is one mechanism of the prebiotic action to generate a bifidogenic shift in the colonic microbiota. However, certain oligosaccharides are able to selectively prevent adhesion of pathogen bacterial species by mimicking binding sites (Saulnier et al., 2009) and others inhibit the expression of genes for some enteropathogens (Gilbreth et al., 2004).

Many examples have shown that prebiotics seem to be more effective when used together with a probiotic as a part of synbiotic combination. The term synbiotic refers to synergism where the prebiotic compound is selectively favored by the live probiotic compound. Maintaining viability of probiotic organisms during manufacture and storage of the products in order to ensure effective delivery of the cells after consumption has been subject of increased interest (Oliveira et al., 2009; Paseephol and Sherkat, 2009; 
Oliveira et al., 2011b; Nazzaro et al., 2012). It is therefore important to select a combination of a specific substrate and a microorganism for a synbiotic product that can improve the beneficial effect compared to products containing a probiotic or a prebiotic alone (Capela et al., 2006; Huebner et al., 2007).

\section{Dairy probiotic/synbiotic foods}

Probiotic/synbiotic foods are a group of functional foods with growing market shares and increasing commercial interest due to proposed health benefits of probiotics and prebiotics. Some of these benefits are established and have been well documented, while the others have shown a promising potential in animal models, with human studies required to confirm these claims (Vasiljevic and Shah, 2008). Functional food products that contain probiotics, prebiotics or synbiotics are mainly classified as dairy products (yoghurt, cheese, ice-cream) (Anal and Singh, 2007) and non-dairy products (vegetables, fruits, grains) (Ranadheera et al., 2010). Dairy foods are the most commercialized functional products as these products are stored at refrigerated conditions and show inherent relationship with probiotic bacteria. In addition dairy matrix provides suitable environment supporting probiotic growth and viability and plays important role in delivering probiotic bacteria to humans (Phillips et al., 2006). Probiotic dairy products are recognized by the consumers as products that contain bioactive compounds beneficial for the general health and therefore they are easily accepted (Kiliç, 2013). Development of these products is a priority in design of functional foods being a challenge for both, scientific and applied research. Furthermore, development of dairy probiotic products requires detailed knowledge of both, products and consumer's attitude and expectations for palatable as well as healthy products (Granato et al., 2010). A successful functional food product development is a scientific approach that is complex and expensive including several criteria as consumer demands, technological conditions and regulatory legislative issues (Jousse, 2008). Consideration of several aspects of any functional food product as functional properties, sensory appeal, shelf-life, physicochemical stability, health claim approval and safety evaluation has to be taken into account, while consumer knowledge of the health benefits of functional compounds may positively affect the acceptance of specific innovative product. However, sensory profile of functional foods containing probiotics and/or prebiotics is still the most important marker of consumer's acceptance of these products. Therefore, even though the consumers are aware that functional product consumption will result in health advantages, the designers of functional foods should take notice to maintain the intrinsic properties of the conventional product. On the other hand, the legislation background of functional products concerns maintenance of nutritional value of conventional products, ensuring claims of no risks related to con- sumption of these products and prohibited use of labeling which may mislead the consumers (Cruz et al., 2010).

The most convenient dairy mediums for application of probiotics are fermented milks and cheeses as they improved the tolerance of probiotic bacteria to the GI conditions after consumption (Lourens-Hattingh and Viljoen, 2001). Although several factors need to be addressed for applying probiotics in dairy products such as physicochemical and sensory properties, health effects and regulation issues, the survival rate of the bacteria in the product gained much importance. Factors that affect the viability of probiotics during the manufacture and storage of fermented milks included acidity, $\mathrm{pH}$, dissolved oxygen content, redox potential, hydrogen peroxide, starter cultures, additives and flavoring compounds which may be present in the products (Phillips et al., 2006; Saarela and Paquin, 2009). Additional factors as probiotic strain, availability of nutrients, growth promoters and inhibitors, inoculation size and incubation temperature, fermentation time, concentration of metabolites such as lactic and acetic acids, buffering capacity of the media and storage temperature, affect the survival rate of bacteria in yoghurt (Donkor et al., 2006; Donkor et al., 2007). The main factors for loss of probiotic viability involved metabolic products of organic acids which further decrease the $\mathrm{pH}$ reached at the end of yoghurt fermentation (Donkor et al., 2006). In order to compensate potential viability loss, inoculation level of probiotics can be increased, but this may negatively affect the quality characteristics of the product (appearance, texture, acidity, and flavor) (Aryana and Mc Grew, 2007). Probiotic inoculation at the end of fermentation is another possibility to achieve improved viability (Vasiljevic and Shah, 2008), while encapsulation of probiotics using different protective agents as alginate, chitosan, starch, pectin, whey proteins, or by adding prebiotics or cysteine into yoghurt are widely used (Capela et al., 2006; Kailasapathy, 2006; Oliveira et al., 2009; Paseephol and Sherkat, 2009; Sandoval-Castilla et al., 2010; Burgain et al., 2011; Cook et al., 2012).

Probiotic viability in yoghurt varied according to large number of strains used and different conditions for preparation and storage of the products. The addition of fruit in yoghurt may have variable effect on the viability of probiotics, since berries might have antimicrobial activities and may lead to further reduction of $\mathrm{pH}$. The loss of viability of $L$. acidophilus was reduced when yoghurt was supplemented with mango and strawberries, while adding of mix berries and passion flower have not provide positive effects on viability compared to the plain yoghurt (Kailasapathy et al., 2008). Other supplements as whey proteins which improve yoghurt buffer capacity and cystein being nutrient for bacterial growth may positively affect the probiotic viability in yoghurt (Ranadheera et al., 2010). The growth and viability of L. acidophilus, L. paracasei subsp. casei and B. bifidum was significantly improved in the presence of cystein during fermentation and storage of yoghurts obtained from goat milk (Güler-Akin and Akin, 2007). Several stud-

Макед. фарм. билт., 60 (2) 3 - 19 (2014) 
ies have reported a positive effect of the prebiotics added to dairy products, both on the viability of probiotic bacteria and on the physicochemical attributes (Castro et al., 2009a; Castro et al., 2009b; Oliveira et al., 2009; Oliveira et al., 2011a; Oliveira et al., 2011b; Debon et al., 2012). However, positive effects of prebiotics on the probiotic viability are variable, since different probiotic strains preferentially use them as substrates. Prebiotics, Hi-maize and inulin improved the growth of L. acidophilus and L. casei in yoghurt as well as organic acids production, but comparison of the prebiotics used has shown more significant effect of inulin on probiotic viability and increased proteolytic activity in the presence of Hi-maize (Donkor et al., 2007). In the study of Capela and co-workers (Capela et al., 2006), fructooligosaccharide was found as the most efficient prebiotic, although Hi-maize and inulin positively affected the viability of L. acidophilus, L. casei, L. rhamnosus and Bifdobacterium sp. in yoghurt.

Cheese is an example of a food matrix that may be a valuable alternative to yoghurt and fermented milks as a vehicle in probiotic delivery contributing to high number of viable bacteria. Namely, cheese has higher $\mathrm{pH}$ and buffering capacity providing good probiotic viability and stability after consumption. More solid consistency and relatively higher fat content are important factors contributing to reduced loss of probiotic viability during GI transit (Bergamini et al., 2005). Since cheese was observed as advantageous in probiotic delivery, general consumption of cheese has increased (da Cruz et al., 2009). Prebiotics inulin and oligofructose improved the viability of both $L$. acidophilus and $B$. animalis subsp. lactis, while eucalyptus honey reduced their survival level in the petit-suisse cheese. It was concluded that the reason may be the low oligosaccharide content of honey. In addition, positive influence of inulin and oligofructose has not been demonstrated only in terms of probiotic viability, but also in improving sensory attributes and consumer acceptance (Cardarelli et al., 2008). Selection of appropriate food matrix to deliver probiotic bacteria is very important as different types of food products have shown variable effect on the probiotic viability, even same strain was used. For example, the viability of $L$. paracasei subsp. paracasei LBC 82 in Minas fresh cheese obtained using lactic acid for direct acidification increased from 6.61 to $8.82 \mathrm{log} \mathrm{cfu} / \mathrm{g}$ during 21 days of storage at $5{ }^{\circ} \mathrm{C}$ (Buriti et al., 2005), while the viability of the same strain in chocolate mousse was slightly increased ( 7.36 to $7.66 \log \mathrm{cfu} / \mathrm{g}$ ) under the same storage conditions (AragonAlegro et al., 2007).

The $\mathrm{pH}$ of the probiotic ice cream that is near to seven and high total solids level including the fat and milk solids provide effective protection for the probiotic bacteria and together with low temperatures of storage are factors contributing frozen dairy desserts to gain popularity as suitable vehicles in probiotic delivery (Homayouni et al., 2012). However, freeze injury and oxygen toxicity may negatively affect the viability of probiotics incorporated into frozen dairy desserts (Kailasapathy and Sultana, 2003; Homayouni et al., 2008d). In the study of Akin and co-workers (Akin et al., 2007) sugar content was found to affect the probiotic viability, while improved viability of $L$. acidophilus and $B$. lactis was noticed in the presence of inulin in the ice cream. Although, adjusting the production and storage conditions of the frozen dairy products is one way to provide higher viability, microencapsulation is an effective approach to enhance the probiotic survival. The growth and survival of L. acidophilus, L. casei, B. lactis and B. longum have been studied in different sucrose concentrations $(10,15,20$ and $25 \%)$, oxygen scavengering components $(0.05 \%$ L-cysteine and $0.05 \%$ L-ascorbate) and low temperatures (4 and $20{ }^{\circ} \mathrm{C}$ ) during 30, 60 and 90 days in MRS broth in order to select suitable strains for manufacture of probiotic ice cream. Results have shown the strains L. casei (Lc 01) and B. lactis ( $\mathrm{Bb} \mathrm{12)}$ as the most appropriate to be incorporated in ice cream as their resistance to simulated acidic and alkaline and ice cream conditions was higher compared to other studied strains (Homayouni et al., 2008b; Homayouni et al., 2008d). This is in accordance to the claim that different probiotic strains are showing variable resistance when studied in the same conditions.

Ayran is a Turkish traditional fermented non-alcoholic beverage manufactured by mixing of yoghurt with salt and water and application of starter cultures (Altay et al., 2013). The product is rich in vitamins and calcium and is easily digestible. Although ayran is one type of yoghurt which is suitable medium for growth and survival of probiotic bacteria, as a vehicle for probiotic delivery it is sparingly studied (Uysal-Pala et al., 2006; Ayar and Burucu, 2013). Therefore, our investigations were directed towards ayran as a matrix to incorporate the probiotic Lactobacillus casei 01 (Chr. Hansen, Hoersholm, Denmark) and the prebiotic Synergy 1 (oligofructose enriched inulin) (Orafti ${ }^{\circledR}$ Synergy 1, Orafti-Rue L. Maréchal, Tienen, Belgium) to prepare functional dairy food (Petreska Ivanovska et al., 2013). Namely, commercially available Ayran (Zdravje Radovo, Macedonia) was enriched with free probiotic, free synbiotic and microencapsulated synbiotic, respectively. For this purpose, microencapsulated synbiotic was previously manufactured using spray-drying method and subsequent freeze-drying (Petreska Ivanovska et al., 2012). The concentrations of biopolymers alginate and chitosan applied to encapsulate the synbiotic and cross-linking agent $\mathrm{CaCl}_{2}$ were optimized using an experimental design to obtain microparticles with relatively high number of viable cells during microencapsulation and storage (Petreska Ivanovska et al., 2014a). Optimized synbiotic formulation effectively protected the probiotic in simulated conditions of the upper GIT (acid $\mathrm{pH}$, bile salts) ensuring therapeutic level of viable cells able to reach and colonize the lower intestine. Moreover, favorable physicochemical properties of the microencapsulated synbiotic (positively charged particles with relatively low diameters) indicated adherence to the intestinal mucosa and controlled delivery of probiotic 
viable cells in the colon.

Qualitative and quantitative examinations (total solids content, $\mathrm{pH}$, titratable acidity, protein, fat and carbohydrate content, salt content) have confirmed that functional samples of ayran containing non-encapsulated probiotic and synbiotic and encapsulated synbiotic maintain the high quality criteria of the conventional product. During the storage of conventional ayran usually syneresis occurs due to compounds aggregation which cannot be prevented by common technological process. Supplementation of ayran by prebiotic or synbiotic increased the solids content and prevented syneresis improving the sensory performance of the prepared functional samples. Herewith, there are data supporting the usage of prebiotic inulin as a fat replacer in skimmed functional dairy products improving their sensory properties (Akin et al., 2007; Cruz et al., 2010). Evaluation of functional properties of the samples prepared in our investigations have shown relatively high level of viable cells indicating the probiotic L. casei 01 is therapeutically active during shelf-life of the product and able to produce lactic, acetic and propionic acids, positively associated with health. The most significant improvement of functional properties of ayran was observed when enriched with microencapsulated synbiotic.

Modern trends are shifting to design and manufacture of non-dairy probiotic/synbiotic food products and food supplements named pharmaceuticals and/or nutraceuticals. The growing interest in the development of non-dairy probiotic foods is linked to the need of commercially available products with decreased allergic potential and without cholesterol. However, problems like sensory performance and consumer acceptance are highly associated with non-dairy products. On the other hand, widespread use of probiotic foods versus probiotic supplementation by pharmaceutical dosage forms may be due to potential synergistic effect of food leading to increased functional efficacy of probiotics. These imply the buffering properties of foods during gastrointestinal transit of probiotic bacteria thus preventing the cell loss, providing nutrients for maintaining the activity and efficacy of the probiotic bacteria and consumer attitude toward use of probiotic food products instead tablets and capsules containing probiotics (de Vrese and Schrezenmeir, 2008; Ranadheera et al., 2010; Del Piano et al., 2011).

\section{Gut microbiota and inflammatory bowel diseases}

The gastrointestinal microbiota is a complex ecosystem of approximately 300-500 bacterial species (Quigley and Quera, 2006). The fetal gut is sterile, and colonization with bacteria is initiated by contact between the child and its environment with the first feed (Palmer, 2007). The bacterial load of the bowel consists of "native" species that permanently colonize the intestine (Tannock, 2007) and transient bacteria that are continuously ingested from the external environment (Damaskos and Kolios, 2008). The stomach and proximal small intestine contain relatively small numbers of bacteria as $10^{3} \mathrm{cfu} / \mathrm{ml}$ due to the normal intestinal motility and the antimicrobial effect of gastric acid and bile. Bacterial counts in the terminal ileum may be as high as $10^{9} \mathrm{cfu} / \mathrm{ml}$, with a predominance of Gram-negative bacteria and anaerobes. At the transition to the colon, bacterial counts arise to $10^{12} \mathrm{cfu} / \mathrm{ml}$ with anaerobic bacteria outnumbering aerobic bacteria by a factor of 100-1000:1 (Neish, 2009). Microbiota in the lower intestine comprised anaerobes such as Bacterioides, Porphyromonas, Bifidobacterium, Lactobacillus and Clostridium. The activity of the intestinal microbiota is mainly expressed in the distal part (Quigley, 2010; Aureli et al., 2011). These bacteria are involved in the maturation of the gut immune system, as it has been demonstrated in animals bred in a germ-free environment (Bauer et al., 2006), which exhibit crypt hyperplasia, lack of lymphoid follicle development and other structural changes (Damaskos and Kolios, 2008). The cells of the gastrointestinal immune system, responsible for the defensive responses against pathogens, are mostly located in the lymphatic structures of lamina propria. Gastrointestinal immune system is consisted of numerous follicular structures and Peyer's patches form part of the specific gutassociated lymphoid system (GALT), together with T lymphocytes, antigen presenting cells (APCs), and B lymphocytes. In the intestinal lamina propria, B cells are differentiated into plasma cells and secrete IgA antibodies that are released into the lumen through binding to a polymeric immunoglobulin receptor transporting them from the basolateral surface of intestinal epithelial cells to the apical surface. Secretory IgA are important elements of mucosal immunity which are resistant to proteolysis and do not activate the complement displaying protective function without pro-inflammatory actions. T lymphocytes as representatives of adaptive immunity are found as CD4+ helper $\mathrm{T}$ lymphocytes with their subsets (Th1, Th2, Th9, and Th17), or as CD8+ T cytotoxic cells and immunosuppressive regulatory $\mathrm{T}$ cells (Tregs). Adaptive immunity includes dendritic cells (DCs) which are APCs able to regulate immune responses to self and foreign antigens guiding the $\mathrm{T}$ cell responses. DCs can also pass through the layer of epithelial cells and capture antigens directly from the lumen. Their contact with antigens or inflammatory stimuli can induce the maturation of DCs accompanied by activation of T cells towards functional and phenotypic differentiation along the Th1/Th2 pathway. In the absence of inflammation, the DCs remain in immature state leading to either deletion of effector T cells or the generation of Tregs (Steinman et al., 2003). Mounting of an effective immune response implies discrimination of harmful antigens by the immune system and tolerance to host microbiota and dietary antigens in the intestines. In fact, mucosal barrier comprising the microbiota, the epithelial lining of the mucosal tissue and the mucus together represent an important defense system against luminal pathogens and immunogenic factors. The lumen containing the microbiota is separated from the GALT 
by epithelial interface (Aureli et al., 2011). Intestinal microbiota has an important role in the diet, maintenance of the mucosal barrier integrity and development of mucosal immunity (Shanahan, 2002). Hence, disruption of the triad comprising secretory IgA, polymeric immunoglobulin receptor and microbes increases the risk of inflammatory disease of intestine (Kaetzel, 2014). The failure to control immune responses leads to breakdown of tolerance towards resident microbiota and inappropriate inflammatory response of the gut immune system to the constituents of the normal microbiota which may ultimately lead to inflammatory conditions such as IBD (Sartor, 2007). Clinical symptoms of IBD include abdominal pain, weakness, rectal bleeding, flushes, edemas, ulcerations, diarrhea, malnutrition, and weight loss (Reiff and Kelly, 2010). Ulcerative colitis is primary located in the colon and proximally to the rectum which becomes inflamed and ulcerated. UC is characterized by superficial mucosal inflammation of the colon, increased number of neutrophils in lamina propria and crypts and production of pro-inflammatory mediators such as interleukin 12 (IL-12) and tumor necrosis factor alpha (TNF- $\alpha$ ) (Geier et al., 2007; Hutfless et al., 2007). Crohn's disease usually affects the lower ileum and colon, although any part of the GIT may be involved. The pathology of CD is characterized by transmural inflammation and aggregation of macrophages stimulating formation of epitheloid granulomas (Geier et al., 2007; Kozuch and Hanauer, 2008). Activation of T helper cell (Th1) responses associated with elevated levels of interferon gamma (IFN- $\gamma$ ) and TNF- $\alpha$ and tissue infiltrate of Th17 cells are characteristic immune pathogenic features in CD (Pene et al., 2008).

Probiotics, prebiotics and synbiotics have the capacity to reverse pathologic changes in gastrointestinal flora and immune tolerance decreasing pathogen attachment and prevent subsequent invasion of the mucosa by blocking binding sites and by up regulating antimicrobial substances in the GIT (Du Pont and Du Pont, 2011). The disproportion of the number of lactobacilli and bifidobacteria in favor of enterobacteria, coliforms and bacteroides in fecal samples of IBD patients (Parkes et al., 2008) also indicated the contribution of the intestinal microbiota to a healthy microbial community.

\section{Probiotics and prebiotics in the management of inflammatory bowel diseases}

The evidence for anti-inflammatory effects of probiotics comes from three types of researches: in vitro studies using cell lines, animal models and clinical studies.

The strain L. fermentum ACA-DC 179 possesses desirable probiotic properties, such as antimicrobial activity and immunomodulation in vitro. Moreover, this strain was successfully applied in an experimental Salmonella enterica-infection mouse model with elevated levels of the anti-inflammatory IL-10. Underlying mechanisms confirmed the potent anti-inflammatory potential of the applied strain, both in vitro and in vivo and have been correlated with improved barrier function and protection against colitis in animal studies (Zoumpopoulou et al., 2008). L. paracasei IBB2588 decreased the adhesion of Salmonella enterica towards Caco-2 cells, so that the pre-incubation of the probiotic provided significantly increased reduction of the pathogen adhesion compared to co-incubation of the probiotic and the pathogen (Jankowska et al., 2008). Strains B. longum Bar33 and L. acidophilus Bar13 competitively inhibited the binding of pathogens to Caco-2 cells and decreased the production of pro-inflammatory cytokine IL-8 in HT-29 cell type indicating immunomodulatory activity (Candela et al., 2008). B. breve and L. lactis, prebiotic GOS or a synbiotic combination demonstrated the ability to exert anti-inflammatory and some anti-proliferative effects in different in vitro models in the context of inflammatory diseases (Grimoud et al., 2010). L. johnsonii induced the production of anti-inflammatory cytokine transforming growth factor- $\beta$ (TGF- $\beta$ ) in leukocyte-sensitized intestinal epithelial cell lines (Haller et al., 2010).

The in vitro results using multiple cell lines should be further evaluated in animal models since confirmation of the observed anti-inflammatory effects taking into account the factors of the environment is necessary to be evaluated. Studies in animal models provided critical insights into pathogenesis of IBD and enabled evaluation of different modalities to prevent or ameliorate inflammation which may be used as relevant evidence in the development of novel therapies for human IBD. Oral administration of probiotics $L$. acidophilus, L. casei and B. lactis have shown intestinal anti-inflammatory activity in the trinitrobenzen sulfonic acid (TNBS) model of rat colitis (Peran et al., 2007a). Reduction in the extent of induced colonic inflammation was observed in this study, and confirmed biochemically by decreased colonic myeloperoxidase (MPO) activity as well as production of TNF- $\alpha$ and inducible nitric oxide synthase (iNOS). However, better efficacy of the $L$. fermentum administration was noticed due to its ability to promote the production of SCFAs into the colon and reduced expression of cyclo-oxygenase-2 (COX-2). In other study of Peran and co-workers (Peran et al., 2007b) each probiotic strain used has shown its own anti-inflammatory properties. B. lactis treatment reduced the production of colonic TNF- $\alpha$, iNOS and COX-2 expressions; L. acidophilus reduced the production of colonic leukotriene $\mathrm{B}_{4}$ and iNOS expression, while $L$. casei decreased the expression of COX-2 in the colon. Biochemically, all the strains applied restored the decreased glutathione levels in the colon as a consequence of the inflammatory process accompanied by oxidative stress. Nishitani and co-workers (Nishitani et al., 2009) used in vivo and in vitro models to evaluate anti-inflammatory effects of the strain Lactococcus lactis subsp. cremoris FC. In the cell assessment, the treatment of a gut inflammation model resulted in significant down-regulation of IL-8 mRNA expression in Caco-2 cells and inhibition of NF- $\mathrm{\kappa B}$ nucle- 
ar translocation in RAW264.7 cells. Administration of the strain in C57BL/6 mice inflamed using dextrane sulfate sodium (DSS) significantly ameliorated histological parameters such as shortening of colon length and tissue inflammation. Intragastric administration of a L. casei BL23 with improved anti-oxidative potential using recombinant technology to obtain strain producing superoxide dismutase resulted in decreased oxidative stress and reduction in the extent of DSS-induced colitis in mice (Watterlot et al., 2010). Oral administration of L. plantarum K68 isolated from Taiwan fermented food $f u$-tsai attenuated DSS-induced ulcerative colitis in BALB/c mice exhibiting anti-inflammatory and immunomodulatory activities (Liu et al., 2011). As it was reported, the disease activity index and histological scores showed significant reduction of the severity of UC. Additionally, the strain has shown significant inhibition of the production of TNF- $\alpha$ and prostaglandin $\mathrm{E}_{2}\left(\mathrm{PGE}_{2}\right)$ in lipopolysaccharide (LPS)-induced murine macrophage RAW 264.7 cells and stimulation of production of IFN- $\gamma$ in human peripheral blood mononuclear cells. Treatment with B. bifidum 17 partially protected mice from Th1-driven inflammation in a chemically induced colitis using relatively high dose of TNBS (120 mg/kg) (Philippe et al., 2011). However, the levels of pro-inflammatory cytokines IL-1 $\beta$, IL-6, keratinocyte-derived chemokine and the inflammatory markers COX-2 and MPO activity as well as histological scores were significantly reduced. Spores from two distinct colony types of the strain Bacilus subtilis PB6 provided as a powder preparation to mice inflamed by $110 \mathrm{mg} / \mathrm{kg}$ TNBS prevented colitis followed by extremely low levels of pro-inflammatory mediators IL-12, TNF- $\alpha$ and IFN- $\gamma$ and stimulation of production of anti-inflammatory IL-10. Macroscopic and histological assessment, blood inflammatory markers and determination of infiltration of mucosal neutrophils were based on blind protocol and compared with the effects of the drug prednisolone (Foligné et al., 2012). L. plantarum CLP-0611 isolated from kimchi ameliorated TNBS-induced colitis in mice inhibiting the expression of IL- $1 \beta$ and IL- 6 , TNF- $\alpha$ production and MPO activity, while inducing NF-kappaB (NF- $\kappa \mathrm{B})$, mitogen-activated protein kinase and polarizing M1 to M2like macrophages (Jang et al., 2014). TNBS-induced colitis $(10 \mathrm{mg} / \mathrm{kg})$ in Wistar rats was significantly ameliorated after 21 days lasting oral administration of $L$. casei loaded whey protein-alginate microparticles suspended in milk as vehicle (Smilkov et al., 2014). Total damage score of the inflamed colon, colon weight/total weight ratio, histological evaluation and activity of MPO, indicated apparent reduction of the inflammation parameters, while treatment with non-encapsulated $L$. case $i$ was effective in reducing inflammation to a lesser extent. This investigation showed the potential of microencapsulated $L$. casei to be used as adjuvant therapy in IBD when incorporated in food product. Our in vivo study comprising different extent of animal model of colitis (induced with 10 and $30 \mathrm{mg} / \mathrm{kg}$ TNBS) has shown the anti-inflammatory potential of prepared probiot- ic (L. casei 01) and synbiotic ayran (L. casei 01 and Synergy 1) (Petreska Ivanovska et al., 2014b). The most significant decrease in parameters of inflammation (body weight, colon weight/length ratio, macroscopic and microscopic ulceration, MPO activity) was observed administering the ayran containing synbiotic chitosan-Ca-alginate microparticles. Determination of bacterial translocation of lactobacilli in extra-intestinal tissues approved the safety issue of the probiotic strain used in the study. The potential of the microencapsulated synbiotic applied in ayran for target and prolonged delivery of active probiotic cells able to colonize the lower GIT should be emphasized, thus showing no concern of increased frequency of the applied treatment.

These studies illustrate different mechanisms of probiotic anti-inflammatory effects comprising inhibition of growth, epithelial adherence and mucosal uptake of enteropathogens, alteration of gut microbial diversity, reduction of mucosal permeability improving the intestinal barrier function and modulation of immune response developing Tregs and tolerogenic dendritic cells (DCs), all contributing to enhanced host-microbiota crosstalk (Reiff and Kelly, 2010).

Literature data summarize the potential use of probiotics in humans applied for remission of UC, pouchitis and CD. Probiotic combination VSL\#3 containing eight lyophilized cultures (L. acidophilus, L. bulgaricus, L. casei, L. plantarum, S. thermophilus, B. breve, B. infantis, and $B$. longum) effectively prevented recurrence of chronic relapsing pouchitis in two double blind and placebo-controlled trials (Gionchetti et al., 2000; Mimura et al., 2004). The same preparation decreased the disease activity index increasing the number of mucosal regulatory $\mathrm{T}$ cells after surgery in patients undergoing ileal pouch anal anastomosis for UC (Pronio et al., 2008), while reduced inflammation in patients with UC up regulating intestinal mucosal alkaline sphingomyelinase was observed (Soo et al., 2008). Remission rate of $56 \%$ assessed through clinical colitis activity index, UC endoscopic score, inflammatory markers, erythrocyte sedimentation rate, C-reactive protein, serum cytokine profile and rectal tissue microbial determinations at beginning and at week eight of VSL\#3 administration in pediatric patients with mild to moderate UC was found (Huynh et al., 2009). Synbiotic therapy experienced increased quality of life compared to probiotic and prebiotic treatment alone in a randomized controlled trial conducted with $100 \mathrm{UC}$ patients divided in three groups, with no adverse effects observed (Fujimori et al., 2009). The results had been summarized on the basis of completed IBD questionnaires at the onset of the study, at the second week and at the forth week including the evaluation of blood variables. A randomized, controlled study consisted of 165 patients with CD who had achieved remission after treatment with steroids or salicylates has shown no significant differences in percentage of patients in remission between group administering Saccharomyces boulardii and placebo group (Bourreille et al., 2013). Another recent study indicated no 
difference in colonic microflora between 8 patients with $\mathrm{CD}$ and 8 patients with $\mathrm{UC}$ who completed one month lasting synbiotic treatment followed by placebo the second month. Measurements of colonic microflora using terminal restriction fragment length polymorphism technique identified the probiotic bacteria in the stool samples, but overall alterations in the microflora spectrum were not found (Ahmed et al., 2013). While studies of animal models of intestinal inflammation enabled promising results, clinical trials are not apparently conclusive probably due to the differences among patients and heterogeneity of inflammatory diseases. Differences between results obtained from animal and human studies might due to differences in the composition of the microbiota in mice and humans, diet, metabolism or immune responses (Shanahan and Quigley, 2014). However, animal models are very helpful to study mechanisms of inflammation, interactions between genetic and environmental factors that increase susceptibility to IBD and host-microbes crosstalk. Moreover, opposing findings are further encourage to well-defined, randomized, double-blind clinical studies with large number of subjects in order to identify specific characteristics related to nature of intestinal inflammation and real role of probiotic/synbiotic treatment for IBD.

Application of prebiotics in the treatment of IBD is also beneficial approach due to findings indicating changes in the gut microbiota of $\mathrm{CD}$ patients and decreased number of bifidobacteria in fecal samples (Lindsay et al., 2006). Prebiotics such as inulin, FOS and barley are able to modify the micro-ecology in the lumen enhancing the growth of Lactobacillus and Bifidobacterium species and providing a substrate for the production of SCFAs by these bacteria. SCFAs are a subset of fatty acids that are produced by the gut microbiota during the fermentation of partially and non-digestible carbohydrates with the highest levels found in the proximal colon, and can be used locally by enterocytes or transported across the gut epithelium into the bloodstream (Tan et al., 2014). SCFAs and especially butyrate are preferred metabolic substrates of colonocytes and can stimulate various mucosal barrier functions. Additionally, immune function may also be modified by these prebiotics changing the dysbiosis towards rebalance and more tolerant response (Sartor, 2004; Guarner, 2007). SCFAs have been found to alter gut integrity and to possess anti-inflammatory, antimicrobial and anticarcinogenic effects, thus playing significant role in maintenance of gut and immune homeostasis (Tan et al., 2014).

Oligosaccharides isolated from goat milk (GMO) contributed to the recovery of damaged colonic mucosa in DSS-treated rats confirmed by decreased MPO activity, up regulation of expression of genes involved in intestinal function as mucine-3 and clinical scoring system (body weight, blood cell counts, presence of blood in the stools) (Lara-Villoslada et al., 2006). In addition, although insignificant, the concentration of SCFAs tended to be higher in rats receiving GMO diet compared to the control rats as well as colon glutathione content, both total and reduced. Intragastric lavage of FOS decreased the severity of the DSS-induced colitis in C57BL/6 mice leading to reduced damage in the distal colon (Winkler et al., 2007), while feeding of Sprague-Dowley rats by FOS reduced caecal inflammation with no effect on colon recovery (Moreau et al., 2003), which is probably due to the different animal models used as well the administration patterns. FOS has shown antagonistic effects in the intestines. Namely, FOS administered as a part of the diet stimulated the growth of lactobacilli and bifidobacteria (Bovee-Oudenhoven et al., 2003), enhanced SCFAs production in the lower intestine which was confirmed in clinical trials (Lewis et al., 2005) and inhibited colonization of pathogens, but FOS can also stimulate bacterial translocation, mucosal irritation and increased activity of MPO in caecum and colon (BoveeOudenhoven et al., 2003). Inconsistency in the data may be the result of fast bacterial fermentation of FOS and overproduction of organic acids that may damage the colonic mucosa. These processes are probably provoked by increased level of FOS in the caecum (Ten-Bruggencate et al., 2005). B. infantis with and without a combination of oligofructose and inulin ameliorated significantly the disease activity index and decreased colonic MPO activity in rats with DSS-induced colitis (Osman et al., 2006). Production of propionic, succinic and butyric acids was also significantly increased, while bacterial translocation to mesenteric lymph nodes and liver decreased significantly in all experimental groups, compared to the colitis control. Increased total concentration of fatty acids in rats fed with prebiotic mixture indicated the inhibitory effects of SCFAs on the inflammation. In the study of Cherbut and co-workers (Cherbut et al., 2003), increased concentrations of lactate and butyrate were determined and reduced damage of the rat colonic mucosa, contributing to the previous conclusion. Inhibition of expression of pro-inflammatory mediators TNF- $\alpha$ and IL- 6 through IFN- $\gamma$-induced macrophages and stimulated production of IL-10 are postulated mechanisms of SCFAs anti-inflammatory effects (Park et al., 2007).

Clinical studies in pediatric patients with CD administered with combination of FOS, inulin and whey proteins have shown reduced severity of the disease associated with decreased sedimentation rate as a biochemical marker of inflammation (Hussey et al., 2003). Bifidogenic effect of FOS was observed analyzing the effect of FOS towards bifidobacteria counts and function of dendrites in mucosa of patients with moderately active CD (Lindsay et al., 2006). Consumption of $15 \mathrm{~g}$ FOS per day significantly reduced the disease activity index providing increased number of bifidobacteria and elevated IL-10 production in lamina propria as a modulator of inflammatory Th1 response. Potential anti-inflammatory effects of prebiotics indicated important contribution to increased power of the probiotic therapy as a synbiotic combination. Meanwhile, evidences from human studies are lacking and immunomodulato- 
ry effects of prebiotics are yet to be researched profound.

\section{Safety aspects of probiotic/synbiotic products}

Usage of probiotic bacteria in health and disease which dates back for centuries is the best evidence for their safety. However, insufficient data, especially when new probiotic strain is a candidate to be placed on the market, constructing of randomized studies for safety evaluation of the probiotic strain is the essence. According to the review of Boyle and co-workers (Boyle et al., 2006) probiotics are characterized with generally safe profile, but should be used with caution in certain population groups such as pregnant women, neonates born prematurely or with immune deficiency. The working groups of WHO and FAO have proposed several criteria that should be considered in order one strain to be defined with the GRAS status (generally regarded as safe): resistance of the probiotic strain to antibiotics, assessment of metabolic properties of the strain (lactate production, bile salts deconjugation), monitoring of adverse effects in clinical studies, epidemiological studies of side effects incidence after approval for commercial use, identification of any substance secreted from the strain that may be toxic for mammals and determination of haemolytic potential of the strain (WHO/FAO, 2002; Petrushevska and Mladenovska, 2009). According to EFSA, qualified presumption of safety of microorganisms of food and feed (QPS) designation could be applied only to microorganisms which may be identified at the strain level and there is a history of apparent safe use (EFSA Scientific Colloquium Summary Report, 2004). Although the characterization of a specific strain is based on the absence of resistance to antibiotics and virulence factors (Barlow et al., 2007), this property is not a major safety issue. Namely, different microorganisms are inherently resistant to the activity of antibiotics and the real concern comes when it is accompanied by a horizontal transfer of genetic determinants (Jansen et al., 2006). Thus, the EU legislation recommends safety assessment for probiotics of food supplements to verify the absence of transferable resistance (Aureli et al., 2011).

Nevertheless, case reports of infections caused by probiotic supplementation containing L. rhamnosus GG (LGG) have been published. Liver abscess and pneumonia was developed in 74-years old diabetic woman after 4 months administration of LGG supplement (Rautio et al., 1999), while endocarditis was diagnosed after dental extraction in 67-years old man with mitral regurgitation who was taking capsules containing L. rhamnosus once daily (Mackay et al., 1999). In both cases the difference between the probiotic and infective L. rhamnosus using pulsed-field gel electrophoresis of chromosomal DNA restriction fragments or standard biochemical analysis was not found, thus the source of infection cannot be conclusively proven. Moreover, cases of probiotic bacteraemia and fungemia have been described in chronic diseases, immuno-com- promised or debilitating subjects (Boyle et al., 2006). Patients with AIDS and Hodgkin have experienced bacteraemia and pulmonary embolism after probiotic supplementation with L. acidophilus (LeDoux et al., 2006). In patients suffering IBD and other diseases where the intestinal barrier may be compromised, there is a risk of translocation of live probiotic across the gut leading to systemic sepsis. Herewith, septicaemia was reported among premature infants with short bowel syndrome who were taking $1 / 4$ LGG capsule daily (De Groote et al., 2005). Increased mortality which was related rather to intestinal ischemia of unknown origin than sepsis was noticed among patients with severe acute pancreatitis administering a probiotic cocktail of 4 lactobacilli and 2 bifidobacteria through a naso-enteric tube (Besselink et al., 2008).

Some reports addressed safety use of probiotics in subjects at higher risk to develop adverse reactions to probiotic supplementation. Study of Kalliomaki and co-workers (Kalliomaki et al., 2001) have shown no side effects related to daily administration of capsules with LGG in 132 pregnant women who were supplemented 2 to 4 weeks before expected delivery. Immuno-compromised HIV-infected patients have not developed adverse effects as a result of consumption of LGG to treat diarrhea (Salminen et al., 2004). No increased trend in bacteraemia cases was found during increased consumption of probiotic products containing Lactobacillus sp. in surveys in Finland (years 1995-1999) and Sweden (years 1998-2004) comprising general population (Salminen et al., 2002; Sullivan and Nord, 2006).

Many prebiotics are constituents of the normal diet and in low concentrations are generally safe for the humans. Clinical studies have not found toxicity effects related to the consumption of prebiotics such as inulin and FOS (Carabin and Flamm, 1999). However, the safety issue of prebiotic administration implies examination of acceptable daily level since the gastrointestinal tolerance for prebiotics is limited. Namely, intestinal fermentation of prebiotics may exceed under increased intake of prebiotics $(>20 \mathrm{~g} /$ day) accompanied by changes in osmotic potential and induction of side effects such as increased gas production, flatulence, abdominal bloating and diarrhea (Tuohy et al., 2005). In order to avoid side effects while remaining beneficial effects, the administration level should be assessed according to targeted population group. School-age children tolerated FOS in the diet at level of $9 \mathrm{~g}$ per day (Carabin and Flamm, 1999), while infants tolerated an intake of 4-8 g prebiotic mix per day (Ziegler et al., 2007). IBD patients have demonstrated tolerance to $15-20 \mathrm{~g}$ FOS per day (Lindsay et al., 2006). According to Bouhnik and co-workwrs (Bouhnik et al., 2004) the relative increase in numbers of faecal bifidobacteria is more dependent on the baseline concentration of bifidobacteria than on the prebiotic dose consumed. In addition, Vanhoutte and co-workers (Vanhoutte et al., 2006) have found that prebiotic consumption was much effective in subjects with low intrinsic level of 
bifidobacteria such as patients with GI disorders and formula fed infants. Taking this into account minimal effective bifidogenic dosage should be recommended.

\section{Summary}

Probiotics have been shown to affect intestinal microbiota, intestinal barrier function and immune responses representing alternative approach in prevention and treatment of IBD. The lack of complete knowledge of the molecular mechanisms involved in pathogenesis of IBD seems to make this issue more complex. In a search for an effective probiotic-based treatment for IBD, scientists have tried to elucidate the underlying mechanisms of probiotic action. The challenge ahead is to gain much understanding of the mechanisms of crosstalk interactions between microbiota and host tissues which will be a contribution to conceptualization of new and successful therapeutic approaches based on clear etiologic, pathogenic processes and predictable responses. Probiotics and prebiotics have been subjected to confer a health benefit in many animal models of intestinal inflammation and clinical studies, but large, rigorously designed and high quality human trials are necessary to be evaluated to investigate individual efficacy of any probiotic strain, dosage, duration of use, single or multi-strain formulation, and the concomitant use of probiotics, prebiotics and antibiotics. Furthermore, it is very important potential antiinflammatory effects mediated by novel probiotic/synbiotic treatments to be highly superior compared to the risks and accepted by the population.

\section{References}

ADA - American Dietetic Association, 2009. Position of the American Dietetic Association: Functional Foods. J. Am. Diet. Assoc. 109, 735-746.

Adolph, T.E., Tomczak, M.F., Niederreiter, L., Ko, H.J., Böck, J., Martinez-Naves, E., Glickman, J.N., Tschurtschenthaler, M., Hartwig, J., Hosomi, S., Flak, M.B., Cusick, J.L., Kohno, K., Iwawaki, T., Billmann-Born, S., Raine, T., Bharti, R., Lucius, R., Kweon, M.N., Marciniak, S.J., Choi, A., Hagen, S.J., Schreiber, S., Rosenstiel, P., Kaser, A., Blumberg, R.S., 2013. Paneth cells as a site of origin for intestinal inflammation. Nature 503(7475), 272-276.

Ahmed, J., Reddy, B.S., Mølbak, L., Leser, T.D., MacFie, J., 2013. Impact on probiotics on colonic microflora in patients with colitis: a prospective double blind randomised crossover study. Int. J. Surg. 11(10), 1131-1136.

Akin, M.B., Akin, M.S., Kirmaci, Z., 2007. Effects of inulin and sugar levels on the viability of yogurt and probiotic bacteria and the physical and sensory characteristics in probiotic icecream. Food Chem. 104(1), 93-99.

Altay, F., Karbancioglu,-Güler, F., Daskaya-Dikmen, C., Heperkan, D., 2013. A review on traditional Turkish fermented nonalcoholic beverages: microbiota, fermentation process and quality characteristics. Int. J. Food Microbiol. 167, 44-56.

Anal, A., Singh, H., 2007. Recent advances in microencapsulation of probiotics for industrial applications and targeted delivery. Trends Food Sci. Technol. 18, 240-251.

Aryana, K.J., Mc Grew, P., 2007. Quality attributes of yoghurt with Lactobacillus casei and various prebiotics. LWT-Food Sci. Technol. 40, 1808-1814.

Ashwell, M., 2002. Concepts of Functional Foods. first ed. ILSIInternational Life Sciences Institute, Brussels.

Aureli, P., Capurso, L., Castellazzi, A.M., Clerici, M., Giovannini, M., Morelli, L., Poli, A., Pregliasco, F., Salvini, F., Zuccotti, G.V., 2011. Probiotics and health: an evidence-based review. Pharmacol. Res. 63, 366-376.

Ayar, A., Burucu, H., 2013. Effect of whey fractions on microbial and physicochemical properties of probiotic ayran (drinkable yogurt). Int. Food Res. J. 20(3), 1409-1415.

Barlow, S., Chesson, A., Collins, J.D., Dybing, E., Flynn, A., Fruijtier Pölloth, C., Hardy, A., Knaap, A., Kuiper, H., Le Neindre, P., Schans, J., Schlatter, J., Silano, V., Skerfving, S., Vannier, P., 2007. Introduction of a qualified presumption of safety (QPS) approach for assessment of selected microorganisms referred to EFSA. Opinion of the Scientific Committee. EFSA J. 587, 1-16.

Bauer, E., Williams, B.A., Smidt, H., Verstegen, M.W., Mosenthin, R., 2006. Influence of the gastrointestinal microbiota on development of the immune system in young animals. Curr. Issues Intest. Microbiol. 7, 35-51.

Bergamini, C.V., Hynes, E.R., Quiberoni, A., Sua'rez, V.B., Zalazar, C.A., 2005. Probiotic bacteria as adjunct starters: influence of the addition methodology on their survival in a semi-hard Argentinean cheese. Food Res. Int. 38(5), 597604.

Bertazzoni Minelli, E., Benini, A., 2008. Relationship between number of bacteria and their probiotic effect. Microb. Ecol. Health. D. 20, 180-183.

Besselink, M.G., van Santvoort, H.C., Buskens, E., Boermeester, M.A., van Goor, H., Timmerman, H.M., Nieuwenhuijs, V.B., Bollen, T.L., Ramshorst, B., Witteman, B.J.M., Rosman, C., Ploeg, R.J., Brink, M.A., Schaapherder, A.F.M., Dejong, C.H.C., Wahab, P.J., van Laarhoven, C.J.H.M., van der Harst, E., van Eijck, C.H.J., Cuesta, M.A., Akkermans, L.M.A., Gooszen, H.G., 2008. Probiotic prophylaxis in predicted severe acute pancreatitis: a randomized, doubleblind, placebo-controlled trial. Lancet 371, 651-659.

Birkett, A.M., Francis, C.C., 2010. Short-chain fructooligosaccharide: a low molecular weight fraction, in Cho S.S., Finocchiaro E.T. (Eds.), Handbook of Prebiotics and Probiotics Ingredients. CRC Press Taylor \& Francis Group, Boca Raton, Florida, pp. 13-42.

Bourneville, A., Cadiot, G., Le Dreau, G., Laharie, D., Beaugerie, L., Dupas, J-L., Marteau, P., Rampal, P., Moyse, D., Saleh, A., Le Guern, M-E., Galmiche, J-P., 2013. Saccharomyces boulardii does not prevent relapse of Crohn's disease. Clin. Gastroenterol. Hepatol. 11, 982-987.

Bovee-Oudenhoven, I., Ten Bruggencate, S., Lettink-Wissink, M., van der Meer, R., 2003. Dietary fructo-oligosaccharides and lactulose inhibit intestinal colonization but stimulate translocation of Salmonella in rats. Br. Med. J. 52(11), 15721578 .

Boyle, R.J., Robins-Browne, R.M., Tang, M.L.K., 2006. Probiotic use in clinical practice: what are the risks? Am. J. Clin. Nutr. $83,1256-1264$.

Burgain, J., Gaiani, C., Linder, M., Scher, J., 2011. Encapsulation of probiotic living cells: from laboratory scale to industrial applications. J. Food Eng. 104, 467-483. 
Candela M., Perna F., Carnevali, P., Vitali, B., Ciati, R., Gionchetti, P., Rizzello, F., Campieri, M., Brigidi, P., 2008. Interaction of probiotic Lactobacillus and Bifidobacterium strains with human intestinal epithelial cells: adhesion properties, competition against enteropathogens and modulation of IL-8 production. Int. J. Food Microbiol. 125, 286-292.

Capela, P., Hay, T.K.C., Shah, N.P., 2006. Effect of cryoprotectants, prebiotics and microencapsulation on survival of probiotic organisms in yoghurt and freeze-dried yoghurt. Food Res. Int. 39(2), 203-211.

Carabin, I.G., Flamm, W.G., 1999. Evaluation of safety of inulin and oligofructose as dietary fiber. Regul. Toxicol. Pharm. 30, 268-282.

Cardarelli, H.R., Buriti, F.C.A., Castro, I.A., Saad, S.M.I., 2008. Inulin and oligofructose improve sensory quality and increase the probiotic viable count in potentially synbiotic petit-suisse cheese. Food Sci. Technol. 41(6), 1037-1046.

Castro, F.P., Cunha, T.M., Ogliari, P.J., Teófilo, R.F., Ferreira, M.M.C., Prudêncio, E.S., 2009a. Influence of different content of cheese whey and oligofructose on the properties of fermented lactic beverages: Study using response surface methodology. LWT-Food Sci. Technol. 42, 993-997.

Castro, F.P., Cunha, T.M., Barreto, P.L.M., Amboni, R.D.M.C., Prudêncio, E.S., 2009b. Effect of oligofructose incorporation on the properties of fermented probiotic lactic beverages. Int. J. Dairy Technol. 62, 74-82.

Ceapa, C., Wopereis, H., Rezaïki, L., Kleerebezem, M., Knol, J., Oozeer, R., 2013. Influence of fermented milk products, prebiotics and probiotics on microbiota composition and health. Best Pract. Res. Clin. Gastroenterol. 27(1), 139-155.

Cherbut, C., Michel, C., Lecannu, G., 2003. The prebiotic characteristics of fructooligosaccharides are necessary for reduction of TNBS-induced colitis in rats. J. Nutr. 133, 2127.

Cook, M.T., Tzortzis, G., Charalampopoulos, D., Khutoryanskiy, V.V., 2012. Microencapsulation of probiotics for gastrointestinal delivery. J. Control. Release 162, 56-67.

Cruz, A.G., Cadena, R.S., Walter, E.H.M., Mortazavian, A.M., Granato, D., Faria, J.A.F., Bolini, H.M.A., 2010. Sensory analysis: relevance for prebiotic, probiotic, and synbiotic product development. Compr. Rev. Food Sci. Food Saf. 9(4), 358-373.

da Cruz, A.G., Buriti, F.C.A., de Souza, C.H.B., Faria, J.A.F., Saad, S.M.I., 2009. Probiotic cheese: health benefits, technological and stability aspects. Trends Food Sci. Technol. 20, 344-354.

Damaskos, D., Kolios, G., 2008. Probiotics and prebiotics in inflammatory bowel disease: microflora "on the scope". Br. J. Clin. Pharmacol. 65(4), 453-467.

Debon, J., Prudêncio, E.S., Petrus, J.C.C., Fritzen-Freire, C.B., Müler, C.M.O., Amboni, R.D.M.C., Vieira, C.R.W., 2012. Storage stability of prebiotic fermented milk obtained from permeate resulting of the microfiltration process. LWT-Food Sci. Technol. 47, 96-102.

De Groote, M.A., Frank, D.N., Dowell, E., Glode, M.P., Pace, N.R., 2005. Lactobacillus rhamnosus GG bacteremia associated with probiotic use in a child with short gut syndrome. Pediatr. Infect. Dis. J. 24, 278-280.

Del Piano, M., Carmagnola, S., Ballarè, M., Sartori M., Orsello, M., Balzarini M., Pagliarulo, M., Tari, R., Anderoni, A., Strozzi, G.P., Mogna, L., Sforza, F., Capurso, L., 2011. Is microencapsulation the future of probiotic preparations? The increased efficacy of gastro-protected probiotics. Gut Microbes 2(2), 120-123. de Vrese, M., Schrezenmeir, J., 2008. Probiotics, prebiotics, and synbiotics. Adv. Biochem. Engin./Biotechnol. 111, 1-66.

Donkor, O., Henriksson, A., Vasiljevic, T., Shah, N.P., 2006. Effect of acidification on the activity of probiotics in yoghurt during cold storage. Int. Dairy J. 16, 1181-1189.

Donkor, O., Nilmini, S., Stolic, P., Vasiljevic, T., Shah, N.P., 2007. Survival and activity of selected probiotic organisms in set-type yoghurt during cold storage. Int. Dairy J. 17(6), 657-665.

Du Pont, A.W., Du Pont, H.L., 2011. The intestinal microbiota and chronic disorders of the gut. Gastroenterol. Hepatol. 8, 523-531.

EFSA Scientific Colloquium Summary Report: QPS qualified presumption of safety of microorganisms in food and feed. Brussels: EFSA, 2004.

Ezaki, S., Itoh, K., Kurishima, C., Tamura, M., 2008. Successful treatment by probiotic enema of necrotizing enterocolitis. Biosci. Microflora 27, 9-11.

FAO/WHO, 2001. Evaluation of health and nutritional properties of powder milk and live lactic acid bacteria. Food and Agriculture Organization of the United Nations and World Health Organization Expert Consultation Report. Rome, Italy.

FAO/WHO, 2002. Guidelines for the evaluation of probiotics in food. Joint FAO/WHO Working Group Report on Drafting Guidelines for the Evaluation of Probiotics in Food. London, Ontario

Foligné, B., Peys, E., Vandenkerckhove, J., Van hemel, J., Dewulf, J., Breton, J., Pot, B., 2012. Spores from two distinct colony types of the strain Bacillus subtilis PB6 substantiate antiinflammatory probiotic effects in mice. Clin. Nutr. 31(6), 987-994.

Fujimori, S., Tatsuquchi, A., Gudis, K., Kishida, T., Mitsui, K., Ehara, A., Kobayashi, K., Sekita, Y., Seo, T., Sakamoto, C. 2007. High dose probiotic and prebiotic cotherapy for remission induction of active Crohn's disease. J. Gastroenterol. Hepatol. 22(8), 1199-1204.

Fujimori, S., Gudis, K., Mitsui, K., Seo, T., Yonezawa, M., Tanaka, S., Tatsuguchi, A., Sakamoto, C., 2009. A randomized controlled trial on the efficacy of synbiotic versus probiotic or prebiotic treatment to improve the quality of life in patients with ulcerative colitis. Nutrition 25, 520-525.

Geier, M.S., Butler, R.N., Howart, G.S., 2006. Probiotics, prebiotics and synbiotics: a role in chemoprevention of colorectal cancer? Cancer Biol. Ther. 5, 1265-1269.

Geier, M.S., Butler, R.N., Howarth, G.S., 2007. Inflammatory bowel disease: Current insights into pathogenesis and new therapeutic options; probiotics, prebiotics and synbiotics. Int. J. Food Microbiol. 115(1), 1-11.

Gibson, G.R., 2004. Fibre and effects on probiotics (the prebiotic concept). Clin. Nutr. Suppl. 1, 25-31.

Gibson, G.R., Probert, H.M., Van Loo, J., Rastall, R.A., Roberfroid, M.B., 2004. Dietary dodulation of the human colonic microbiota: updating the concept of prebiotics. Nutr. Res. Rev. 17, 259-275.

Gilbreth, S.E., Benson, A.K., Hutkins, R.W., 2004. Catabolite repression and virulence gene expression in Listeria monocytogenes. Curr. Microbiol. 49, 95-98.

Gill, H., Prasad, J., 2008. Probiotics, immunomodulation, and health benefits. Adv. Exp. Med. Biol. 606, 423-454.

Gionchetti, P., Rizzello, F., Venturi A., Brigidi, P., Matteuzzi, D., Bazzocchi, G., Poggioli, G., Miglioli, M., Campieri 
M., 2000. Oral bacteriotherapy as maintance treatment in patients with chronic pouchitis: a double blind, placebocontrolled trial. Gastroenterology 119, 305-309.

Granato, D., Branco, G.F., Cruz, A.G., Faria, J.A.F., Shah, N.P., 2010. Probiotic dairy products as functional foods. Compr. Rev. Food Sci. Food Saf. 9, 455-470.

Grimoud, J., Durand, H., de Souza, S., Monsan, P., Ouarné, F., Theodorou, V., Roques, C., 2010. In vitro screening of probiotics and synbiotics according to anti-inflammatory and anti-proliferative effects. Int. J. Food Microbiol. 144, 42-50.

Guarner, F., Malagelada, J., 2003. Gut flora in health and disease. Lancet 361, 512-519.

Guarner, F., 2007. Prebiotics in inflammatory bowel diseases. Br. J. Nutr. 98(Suppl 1), S85-89.

Guarner, F., 2013. Impacts of prebiotics on the immune system and inflammation, in: Calder, P.C., Yagoob, P. (Eds.), Diet Immunity and Inflammation. Woodhead Publishing, 11, 292-312.

Güler-Akin, M.B., Akin, M.S., 2007. Effects of cysteine and different incubation temperatures on the microflora, chemical composition and sensory characteristics of bio-yogurt made from goat's milk. Food Chem. 100(2), 788-793.

Haller, D., Antoine, J.M., Bengmark, S., Enck, P., Rijkers, G.T., Lenoir-Wijnkoop, I., 2010. Guidance for substantiating the evidence for beneficial effects of probiotics: probiotics in chronic inflammatory bowel disease and the functional disorder irritable bowel syndrome. J. Nutr. 140(3), 690S-697S.

Hayek, S.A., Ibrahim, S.A., 2013. Current limitations and challenges with lactic acid bacteria: a review. Food Nutr. Sci. 4, 73-87.

He, T., Priebe, M.G., Zhong, Y., Huang, C., Harmsen, H.J.M., Raangs, G.C., Antoine, J.M., Welling, G.W., Wonk, R.J., 2008. Effects of yogurt and bifidobacteria supplementation on the colonic microbiota in lactose-intolerant subjects. J. Appl. Microbiol. 104, 595-604.

Homayouni, A., Azizi, A., Ehsani, M.R., Yarmand, M.S., Razavi, S.H., 2008b. Effect of microencapsulation and resistant starch on the probiotic survival and sensory properties of synbiotic ice cream. Food Chem. 111, 50-55.

Homayouni, A., Ehsani, M.R., Azizi, A., Razavi, S.H., Yarmand, M.S., 2008d. Growth and survival of some probiotic strains in simulated ice cream conditions. J. Appl. Sci. 8(2), 379382 .

Homayouni, A., Azizi, A., Javadi, M., Mahdipour, S., Ejtahed, H., 2012. Factors influencing probiotic survival in ice cream: a review. Int. J. Dairy Sci. 7(1), 1-10.

Hörmannsperger, G., Haller, D., 2010. Molecular crosstalk of probiotic bacteria with the intestinal immune system: clinical relevance in the context of inflammatory bowel disease. Int. J. Med. Microbiol. 300, 63-73.

Huebner, J., Wehling, R.L., Hutkins, R.W., 2007. Functional activity of commercial prebiotics. Int. Dairy J. 17, 770-775.

Hutfless, S.M., Weng, X., Liu, L., Allison, J., Herrinton, L.J., 2007. Mortality by medication use among patients with inflammatory bowel disease, 1996-2003. Gastroenterology 133(6), 1779-1786.

Huynh, H.Q., deBruyn, J., Guan, L., Diaz, H., Li, M., Girgis, S., Turner, J., Fedorak, R., Madsen, K., 2009. Probiotic preparation VSL\#3 induces remission in children with mild to moderate acute ulcerative colitis: a pilot study. Inflamm Bowel Dis. 15(5), 760-768.

Jang, S-E., Han, M.J., Kim, S-Y., Kim, D-H., 2014. Lactobacillus plantarum CLP-0611 ameliorates colitis in mice by polarizing M1 to M2-like macrophages. Int Immunopharmacol. 21(1), 186-192.

Jankowska, A., Laubitz, D., Antushevich, H., Zabielski, R., Grzesiuk, E., 2008. Competion of Lactobacillus paracasei with Salmonella enterica for adhesion to Caco2 cells. J. Biomed. Biotechnol. Article ID 357964, 6 pages, doi:10.1155/2008/357964.

Jansen, W.T., van der Bruggen, J.T., Verhoef, J., Fluit, A.C., 2006. Bacterial resistance: a sensitive issue complexity of the challenge and containment strategy in Europe. Drug Resist. Update 9, 123-133.

Jousse, F., 2008. Modeling to improve the efficiency of product and process development. Compr. Rev. Food Sci. Food Saf. 7, 175-181.

Kaetzel, C.S., Cooperativity among secretory $\operatorname{IgA}$, the polymeric immunoglobulin receptor, and the gut microbiota promotes host-microbial mutualism. Immunol. Lett. 162(2), 10-21.

Kailasapathy, K., Sultana, K., 2003. Survival and $\beta$-Dgalactosidase activity of encapsulated and free Lactobacillus acidophilus and Bifidobacterium lactis in ice cream. Aust. J. Dairy Technol. 58, 223-227.

Kailasapathy, K., 2006. Survival of free and encapsulated probiotic bacteria and their effect on the sensory properties of yoghurt. LWT-Food Sci. Technol. 39(10), 1221-1227.

Kailasapathy, K., Harmstorf, I., Phillips, M., 2008. Survival of Lactobacillus acidophilus and Bifidobacterium animalis ssp. lactis in stirred fruit yoghurts. LWT-Food Sci. Technol. 41(7), 1317-1322.

Kalliomaki, M., Salminen, S., Arvilomni, H., Kero, P., Koskinen, P., Isolauri, E., 2001. Probiotics in primary prevention of atopic disease: a randomized placebo-controlled trial. Lancet 357, 1076-1079.

Kaser, A., Blumberg, R.S., 2011. Autophagy, microbial sensing, endoplasmic reticulum stress, and epithelial function in inflammatory bowel disease. Gastroenterology 140(6), 1738-1747.

K1lıç, G.B., 2013. Highlights in Probiotic Research, in: Kongo, M. (Eds.), Lactic Acid Bacteria - R \& D for Food, Health and Livestock Purposes. InTech, DOI: 10.5772/50004. Available from: http://www.intechopen.com/books/lacticacid-bacteria-r-d-for-food-health-and-livestock-purposes/ highlights-in-probiotic-research

Kozuch, P.L., Hanauer, S.B., 2008. Treatment of inflammatory bowel disease: a review of medical therapy. World J. Gastroenterol. 14(3), 354-377.

Kukkonen, K., Savilahti, E., Haahtela, T., 2007. Probiotics and prebiotic galacto-oligosaccharides in the prevention of allergic diseases: a randomized, double-blined, placebo controlled trial. J. Allergy Clin. Immunol. 119, 192-198.

Lara-Villoslada, F., Debras, E., Nieto, A., Concha, A., Galvez, J., Lopez-Huertas, E., Boza, J., Obled, C., Xaus, J., 2006. Oligosaccharides isolated from goat milk reduce intestinal inflammation in a rat model of dextran sodium sulfateinduced colitis. Clin. Nutr. 25(3), 477-488.

LeDoux, D., LaBombardi, V.J., Karter, D., 2006. Lactobacillus acidophilus bacteraemia after use of a probiotic in a patient with AIDS and Hodgkin's disease. Int. J. Std. Aids. 17, 280282.

Lindsay, J.O., Whelan, K., Stagg, A.J., Gobin, P., Al-Hassi, H.O., Rayment, N., Kamm, M.A., Knight, S.C., Forbes, A., 2006. Clinical, microbiological, and immunological effects of fructo-oligosaccharide in patients with Crohn's disease. Gut 
55, 348-355.

Liu, Y-W., Su, Y-W., Ong, W-K., Cheng, T-H., Tsai, Y-C., 2011. Oral administration of Lactobacillus plantarum K68 ameliorates DSS-induced ulcerative colitis in BALB/c mice via the anti-inflammatory and immunomodulatory activities. Int. Immunopharmacol. 11, 2159-2168.

Looijer-van Langen, M.A.C., Dieleman, L.A., 2009. Prebiotics in chronic intestinal inflammation. Inflamm. Bowel Dis. 15(3), 454-462.

Lourens-Hattingh, A., Viljoen, B.C., 2001. Yoghurt as probiotic carrier in food. Int. Dairy J. 11, 1-17.

Lye, H.-S., Kuan, C.-Y., Ewe, J.-A., Fung, W.-Y., Liong, M.T., 2009. The improvement of hypertension by probiotics: effects on cholesterol, diabetes, renin, and phytoestrogens. Int. J. Mol. Sci. 10, 3755-3775.

Macfarlane, S., Macfarlane, G.T., Cummings, J.H., 2006. Prebiotics in the gastrointestinal tract. Aliment. Pharmacol. Ther. 24, 701-714.

Macfarlane, G.T., Steed, H., Macfarlane, S., 2008. Bacterial metabolism and health-related effects of galactooligosaccharides and other prebiotics. J. Appl. Microbiol. 104, 305-344.

Mackay, A.D., Taylor, M.B., Kibbler, C.C., Hamilton-Miller, J.M., 1999. Lactobacillus endocarditis caused by a probiotic organism. Clin. Microbiol. Infect. 5, 290-292.

Metchnikoff E., 1907. The prolongation of life: Optimistic studies. London: Butterworth-Heinemann, London.

Meyer, D., Stasse-Wolthuis, M., 2009. The bifidogenic effect of inulin and oligofructose and its consequences for gut health. Eur. J. Clin. Nutr. 63, 1277-1289.

Mimura, T., Rizzello, F., Helwig, U., Poggioli, G., Schreiber, S., Talbot, L.C., Nicholis, R.J., Gionchetti, P., Campieri M., Kamm, M.A., 2004. Once daily high dose probiotic therapy (VSL\#3) for maintaining remission in recurrent or refractory pouchitis. Gut 53, 108-114.

Moreau, N.M., Martin, L.J., Toquet, C.S., Laboisse, C.L., Nguyen, P.G., Siliart, B.S., Dumon, H.J., Champ, M.M., 2003. Restoration of the integrity of rat caeco-colonic mucosa by resistant starch, but not by fructo-oligosaccharides in dextran sulfate sodium-induced experimental colitis. Br. J. Nutr. 90(1), 75-85.

Nazzaro, F., Fratianni, F., Nicolaus, B., Poli, A., Orlando, P., 2012. The prebiotic source influences the growth, biochemical features and survival under simulated gastrointestinal conditions of the probiotic Lactobacillus acidophilus. Anaerobe 18, 280-285.

Neish, A.S., 2009. Microbes in gastrointestinal health and disease. Gastroenterology 136, 65-80.

Neuman, M.G., Nanau, R.M., 2012. Inflamatory bowel disease: role of diet, microbiota, life style. Translational. Res. 160(1), 29-44.

Nishitani, Y., Tanoue, T., Yamada, K., Ishida, T., Toshida, M., Azuma, T., Mizuno, M., 2009. Lactococcus lactis subsp. cremoris FC alleviates symptoms of colitis induced by dextran sulfate sodium in mice. Int. Immunopharmacol. 9, 1444-1451.

Oliveira, R.P.S., Florence, A.C.R., Silva, R.C., Perego, P., Converti, A., Gioeilli, A.L., Oliveira, M.N., 2009. Effect of different prebiotics on the fermentation kinetics, probiotic survival and fatty acids profiles in non-fat synbiotic fermented milk. Int. J. Food Microbiol. 128(3), 467-472.

Oliveira, R.P.S., Perego, P., Oliveira, M.N., Converti, A., 2011a. Effect of inulin as prebiotic and synbiotic interactions between probiotics to improve fermented milk firmness. J. Food Eng. 107, 36-40.

Oliveira, R.P.S., Perego, P., Oliveira, M.N., Converti, A., 2011 b. Effect of inulin as a prebiotic to improve growth and counts of a probiotic cocktail in fermented skim milk. LWT-Food Sci. Technol. 44(2), 520-523.

Osman, N., Adawi, D., Molin, G., Ahrne, S., Berggren, A., Jeppsson, B., 2006. Bifidobacterium infantis strains with and without a combination of oligofructose and inulin (OFI) attenuate inflammation in DSS-induced colitis in rats. BMC Gastroenterol, 6, 31.

Ouwehand, A.C., Röytiö, H., 2015. Probiotic fermented foods and health promotion, In: Holzapfel, W. (Eds.), Advances in Fermented Foods and Beverages. Woodhead Publishing, pp. 3-22.

Palmer, C., Bik, E.M., DiGiulio, D.B., Relman, D.A., Brown, P.O., 2007. Development of the human infant intestinal microbiota. PloS Biol. 5, 1556-1573.

Park, J.S., Lee, E.J., Lee, J.C., Kim, W.K., Kim, H.S., 2007. Anti-Inflammatory effects of short chain fatty acids in IFNgamma-stimulated RAW 264.7 murine macrophage cells: involvement of NF-kappa B and ERK signaling pathways. Int. Immunopharmacol. 7, 70-77.

Parkes, G.C., Brostoff, J., Whelan, K., Sanderson, J.D., 2008. Gastrointestinal microbiota in irritable bowel syndrome: their role in its pathogenesis and treatment. Am. J. Gastroenterol. 103, 1557-1567.

Paseephol, T, Sherkat, F., 2009. Probiotic stability of yoghurts containing Jerusalem artichoke insulin during refrigerated storage. J. Funct. Foods 1(3), 311-318.

Pene, J., Chevalier, S., Preisser, L., Venereau, E., Guilleux, M.H., Ghannam, S., Moles, J.P., Danger, Y., Ravon, E., Lesaux, S., Yssel, H., Gascan, H., 2008. Chronically inflamed human tissues are infiltrated by highly differentiated Th17 lymphocytes. J. Immunol. 180, 7423-7430.

Peran L., Sierra, S., Comalada M., Lara-Villoslada, F., Bailon E., Nieto A., Concha, A., Olivares, M., Zarzuelo A., Xaus J., Galvez J., 2007a. A comparative study of the preventive effects exerted by two probiotics, Lactobacillus reuteri and Lactobacillus fermentum, in the trinitrobenzensulfonic acid model of rat colitis. Br. J. Nutr. 97(1), 96-103.

Peran L., Camuesco D., Comalada M., Bailon E., Henriksson A., Xaus J., Zarzuelo A., Galvez J., 2007b. A comparative study of the preventive effects exerted by three probiotics, Bifidobacterium lactis, Lactobacillus casei and Lactobacillus acidophilus, in the TNBS model of rat colitis. J. Appl. Microbiol. 103, 836-844.

Petreska Ivanovska, T., Petrushevska-Tozi, L., Dabevska Kostoska, M., Geskovski, N., Grozdanov, A., Stain, C. Stafilov, T., Mladenovska, K., 2012. Microencapsulation of L. casei in chitosan-Ca-alginate microparticles using spraydrying method. Mac. J. Chem. Chem. Eng. 31(1), 115-123.

Petreska Ivanovska, T., Petrushevska-Tozi, L., Mladenovska, K., 2013. Improvement of functional properties of ayran using synbiotic microparticles. Proceedings of the 4-th Congress of Food Supplements with international participation, Belgrade.

Petreska Ivanovska, T., Petrushevska-Tozi, L., Grozdanov, A., Petkovska, R., Hadjieva, J., Popovski, E., Stafilov, T., Mladenovska., K., 2014a. From optimization of synbiotic microparticles prepared by spray-drying to development of new functional carrot juice. Chem. Ind. Chem. Eng. Quart. 20(4), 549-564. 
Petreska Ivanovska, T., Gjurovski, I., Jurhar-Pavlova, M., Petrushevska-Tozi, L., Ristoski, T., Mladenovska, K., 2014b. Pathological changes of colon in the TNBS model of colitis in rats treated with functional food containing probiotic/ synbiotic formulation. Proceedings of the 2-nd Joint European Congress of the ESVP, ESTP and ECVP, Berlin.

Petrushevska Tozi, L., Mladenovska, K., 2009. Functional probiotic and synbiotic food products-advances in production, evaluation and health benefit, in Injac, R. (Eds.), The Analysis of pharmacologically active compounds and biomolecules in real samples. Transworld Research Network, Kerala, pp. 129-164.

Philippe, D., Heupel, E., Blum-Sperisen, S., Riedel, U., 2011. Treatment with Bifidobacterium bifidum 17 partially protects mice from Th1-driven inflammation in a chemically induced model of colitis. Int. J. Food Microbiol. 149, 45-49.

Phillips, M., Kailasapathy, K., Tran, L., 2006. Viability of commercial probiotic cultures ( $L$. acidophilus, Bifidobacterium sp., L. casei, L. paracasei, and L. rhamnosus) in Cheddar cheese. Int. J. Food Microbiol. 108, 276-280.

Prakash, S., Tomaro-Duchesneau, C., Saha, S., Cantor, A., 2011. The gut microbiota and human health: an emphasis on the use of microencapsulated bacterial cells. J. Biomed. Biotechnol. 2-12.

Prisciandaro, L., Geier, M., Butler, R., Cummins, A., Howarth, G., 2009. Probiotics and their derivatives as treatments for inflammatory bowel disease. Inflamm. Bowel Dis. 15(12), 1906-1914.

Pronio, A., Montesani, C., Butteroni, C., Vecchione, S., Mumolo, G., Vestri, A., Vitolo, D., Boirivant, M., 2008. Probiotic administration in patients with ileal pouch-anal anastomosis for ulcerative colitis is associated with expansion of mucosal regulatory cells. Inflamm. Bowel Dis. 14, 662-668.

Quigley, E.M.M., Quera, R., 2006. Small intestinal bacterial overgrowth: roles of antibiotics, prebiotics, and probiotics. Gastroenterology 130, 78-90.

Quigley, E.M.M., 2010. Prebiotics and probiotics modifying and mining microbiota. Pharmacol. Res. 61(3), 213-218.

Ranadheera, R.D.C.S., Baines, S.K., Adams, M.C., 2010. Importance of food in probiotic efficacy. Food Res. Int. 43, 1-7.

Rautio, M., Jousimies-Somer, H., Kauma, H., Pietarinen, I., Saxelin, M., Tynkkynen, S., Koskela, M., 1999. Liver abscess due to a Lactobacillus rhamnosus strain indistinguishable from L-rhamnosus strain GG. Clin. Infect. Dis. 28, 1159-1160.

Reiff, C., Kelly, D., 2010. Inflammatory bowel disease, gut bacteria and probiotic therapy. Int. J. Med. Microbiol. 300, 25-33.

Saarela, M., Mogensen, G., Fonden, R., Matto, J., MattilaSandholm, T., 2000. Probiotic bacteria: safety, functional and technological properties. J. Biotechnol. 84, 197-215.

Saarela, M., Paquin, P., 2009. Probiotics as ingredients in functional beverages. In: Paquin, P. (Eds.), Functional and Specialty Beverage Technology. CRC Press, New York, pp. 55-70.

Salminen, M.K., Tynkkynen, S., Rautelin, H., Saxelin, M., Vaara, M., Ruutu, P., Sarna, S., Valtonen, V., Jarvinen, A., 2002. Lactobacillus bacteremia during a rapid increase in probiotic use of Lactobacillus rhamnosus GG in Finland. Clin. Infect. Dis. 35, 1155-1160.

Salminen, M.K., Tynkkynen, S., Rautelin, H., Poussa, T., Saxelin, M., Ristola, M., Valtonen, V., Jarvinen, A., 2004. The efficacy and safety of probiotic Lactobacillus rhamnosus GG on prolonged, noninfectious diarrhea in HIV patients on antiretroviral therapy: a randomized, placebo-controlled, crossover study. HIV Clin. Trials 5, 183-191.

Sandoval-Castilla, O., Lobato-Calleros, C., Garcia-Galindo, H.S., Alvarez-Ramirez, J., Vernon-Carter E.J., 2010. Textural properties of alginate-pectin beads and survivability of entrapped $L b$. casei in simulated gastrointestinal conditions and in yoghurt. Food Res. Int. 43, 111-117.

Sartor, B.R., 2004. Therapeutic manipulation of the enteric microflora in inflammatory bowel diseases: antibiotics, probiotics, and prebiotics. Gastroenterology 126, 16201633.

Sartor, R.B., Muehlbauer, M., 2007. Microbial host interactions in IBD: implications for pathogenesis and therapy. Curr. Gastroenterol. Rep. 9, 497-507.

Saulnier, D.M.A., Spinler, J.K., Gibson, G.R., Versalovic, J., 2009. Mechanisms of probiosis and prebiosis: considerations for enhanced functional foods. Curr. Opin. Biotechnol. 20, 135-141.

Senok, A.C., Ismaeel, A.Y., Botta, G.A., 2005. Probiotics: Facts and myths. Clin. Microbiol. Infect. 11(12), 958-966.

Shanahan, F., 2002. The host-microbe interface within the gut. Best Pract. Res. Clin. Gastroenterol. 16, 915-931.

Shanahan, F., Quigley, E.M.M., Manipulation of the microbiota for treatment of IBS and IBD-challenges and controversies. Gastroenterology 146(6), 1554-1563.

Shanahan, F., 2012. The gut microbiota-a clinical perspective on lessons learned. Nat. Rev. Gastroenterol. Hepatol. 9, 609-614.

Smilkov, K., Glavas Dodov, M., Hadzieva, J., Jurhar-Pavlova, M., Petreska Ivanovska, T., Ristoski T., Gjurovski, I., Petrushevska-Tozi, L., Mladenovska, K., 2014. Antiinflammatory properties of $L$. casei loaded whey proteinalginate microparticles in animal model of colitis. Proceedings of the 9-th World Meeting of Pharmaceutics, Biopharmaceutics and Pharmaceutical Technology, Lisbon.

So, J.S., Kwon, H.K., Lee, C.G., Yi, H.J., Park, J.A., Lim, S.Y., Hwang, K.C., Yeon, Y.H., Im, S.H., 2008. Lactobacillus casei suppresses experimental arthritis by down-regulating T helper 1 effector functions. Mol. Immunol. 45, 2690-2699.

Soo, L., Madsen, K.L., Tejpar, Q., Sydora, B.C., Sherbaniuk, R., Cinque, B., Di Marzio, L., Cifone, M.G., Desimone, C., Fedorak, R.N., 2008. VSL\#3 probiotic upreulates intestinal mucosal alkaline sphingomyelinase and reduces inflammation. Can. J. Gastroenterol. 22, 237-242.

Steinman, R.M., Hawiger, D., Nussenzweig, M.G., 2003. Tolerogenic dendritic cells. Annu. Rev. Immunol. 21, 685-711.

Strober, W., Fuss, I., Mannon, P., 2007. The fundamental basis of inflammatory bowel disease. J. Clin. Invest. 117(3), 514-521.

Sullivan, A., Nord, C.E., 2006. Probiotic lactobacilli and bacteraemia in Stockholm. Scand. J. Infect. Dis. 38, 327-331.

Tannock, G.W., 2007. What immunologists should know about bacterial communities of the human bowel. Semin. Immunol. 19, 94-105.

Tan, J., McKenzie, C., Potamitis, M., Thornburn, A.N., Mackay, C.R., Macia, L., 2014. The role of short-chain fatty acids in health and disease. Adv. Immunol. 121, 91-119.

Ten Bruggencate, S.J., Bovee-Oudenhoven, I.M., LettinkWissink, M.L., van der Meer, R., 2005. Dietary fructooligosaccharides increase intestinal permeability in rats. J. Nutr. 135(4), 837-842.

Tissier H., 1984. Taxonomy and ecology of bifidobacteria. Bifidobacteria Microflora 3, 11-28.

Tuohy, K.M., Rouzaud, G.C.M., Bruck, W.M., Gibson, G.R., 2005. Modulation of the human gut microflora towards 
improved health using prebiotics-assessment of efficacy. Curr. Pharm. Design 11(1), 75-90.

Uysal-Pala, C., Karagul-Yuceer, Y., Pala, A., Savas, T., 2006. Sensory properties of drinkable yoghurt made from milk of different goat breeds. J. Sens. Stud. 21, 520-533.

Vanhoutte, T., De Preter, V., De Brandt, E., Verbeke, K., Swings, J., Huys, G., 2006. Molecular monitoring of the fecal microbiota of healthy human subjects during administration of lactulose and Saccharomyces boulardii. Appl. Environ. Microbiol. 72, 5990-5997.

Vasiljevic, T., Shah, N.P., 2008. Probiotics-from Metchnikoff to bioactives. Int. Dairy. J. 18, 714-728.

Wapenaar, M.C., Monsuur, A.J., van Bodegraven, A.A., Weersma, R.K., Revova, M.R., Linskens, R.K., Howdle, P., Holmes, G., Mulder, C.J., Dijkstra, G., van Heel, D.A., Wijmenga, C., 2008. Association with tight junction genes PARD3 and MAGI2 in Dutch patients point to a common barrier defect for coeliac disease and ulcerative colitis. Gut 57, 463-467.

Watterlot, L., Rochat, T., Sokol, H., Cherbuy, C., Bouloufa, I., Lefèvre, F., Gratadoux, J-J., Honvo-Hueto, E., Chilmonczyk, S., Blugeon, S., Corthier, G., Langella, P., BermúdezHumarán, L.G., 2010. Intragastric administration of a superoxide dismutase-producing recombinant Lactobacillus casei BL23 strain attenuates DSS colitis in mice. Int. J. Food Microbiol. 144, 35-41.

Wickens, K., Black, P.N., Stanley, T.V., 2008. A differential effect of 2 probiotics in the prevention of eczema and atopy: a doble-blined, randomized, placebo-controlled trial. J. Allergy Clin. Immunol. 122, 788-794.

Winkler, J., Butler, R., Symonds, E., 2007. Fructo-oligosaccharide reduces inflammation in a dextran sodium sulphate mouse model of colitis. Dig. Dis. Sci. 52(1), 52-58.

Ziegler, E., Vanderhoof, J.A., Petschow, B., Mitmesser, S.H., Stolz, S.I., Harris, C.L., Berseth, C.L., 2007. Term infants fed formula supplemented with selected blends of prebiotics grow normally and have soft stools similar to those reported for breast-fed infants. J. Pediatr. Gastroenterol. Nutr. 44, 359-364.

Zoumpopoulou, G., Foligne, B., Christodoulou, K., Grangette, C., Pot, B., Tsakalidou, E., 2008. Lactobacillus fermentum ACA-DC 179 displays probiotic potential in vitro and protects against trinitrobenzene sulfonic acid (TNBS)induced colitis and Salmonella infection in murine models. Int. J. Food Microbiol. 121(1), 18-26.

\title{
Пробиотици, пребиотици и синбиотици во превенција и третман на инфламаторни цревни заболувања
}

\author{
Тања Петреска Ивановска ${ }^{1 *}$, Маја Јурхар Павлова², Кристина Младеновска ${ }^{1}$ \\ Лидија Петрушевска-Този ${ }^{1}$
}

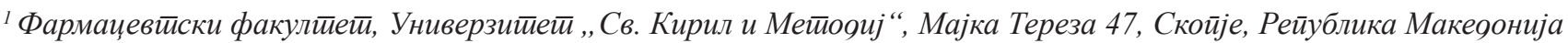

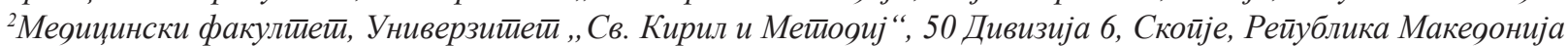

Клучни зборови: пробиотик, пребиотик, синбиотик, функционална храна, инфламаторно цревно заболување

Пробиотиците, пребиотиците и синбиотиците претставуваат функционални состојки кои покажуваат поволни ефекти врз здравјето на луѓето. Интересот за пробиотиците, пребиотиците и синбиотиците произлегува од потенцијалната примена во превенцијата и третманот на голем број заболувања и медицински состојби за кои недостасува ефикасен и безбеден пристап. Придобивките од употребата на овие биоактивни состојки се состојат и во намалување на морбидитетот на хроничните заболувања и трошокот за здравствената грижа. За испорака на пробиотиците/ синбиотиците во гастроинтестиналниот тракт се користат различни видови на медиуми. Главниот предизвик на комерцијалниот сектор е да овозможи присуство на нови функционални прехранбени производи со пробиотици и/или пребиотици на пазарот, и покрај тоа што предмет на интерес се и пробиотските капсули и таблети. Дизајнот на новите пробиотски/синбиотски прехранбени производи е резултат на интересот на прехранбената индустрија за континуиран напредок од аспект на подобрување на нутритивните и сензорните својства на производите, како и здравствените придобивки за потрошувачите. Целта на ова издание е да овозможи пошироко согледување и нови перспективи во употребата на функционалните компоненти и производи во превенција и третман на инфламаторните цревни заболувања (ИЦЗ) кои се тесно поврзани со современиот начин на живот. Дискусијата ги опфаќа терапевтските и безбедносните карактеристики на пробиотиците и пребиотиците, нивната улога во патогенезата на ИЦЗ, механизмите на дејство и значењето во превенцијата и третманот на овие заболувања, со истакнување на клучните фактори кои се неопходен предмет на понатамошни истражувања. 
